Review

\title{
Wasp venomic: Unravelling the toxins arsenal of Polybia paulista venom and its potential pharmaceutical applications
}

\author{
Amilcar Perez-Riverol a , José Roberto Aparecido dos Santos-Pinto ${ }^{\mathrm{b}}$, Alexis Musacchio Lasa ${ }^{\mathrm{c}}$, \\ Mario Sergio Palma ${ }^{\mathrm{b}, * *}$, Márcia Regina Brochetto-Braga ${ }^{\mathrm{a}, \mathrm{d}, *}$ \\ a Laboratório de Biologia Molecular de Artrópodes-LBMA-IBRC-UNESP (Univ Estadual Paulista), Av. 24-A, $n^{\circ}$ 1515, CEP 13506-900, Bela Vista, Rio Claro, SP, Brazil \\ ${ }^{b}$ Centro de Estudos de Insetos Sociais-CEIS-IBRC-UNESP (Univ Estadual Paulista), Av. 24-A, $n^{\circ}$ 1515, CEP 13506-900, Bela Vista, Rio Claro, SP, Brazil

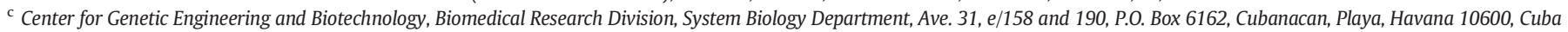 \\ d Centro de Estudos de Venenos e Animais Peçonhentos-CEVAP (Univ Estadual Paulista), Rua José Barbosa de Barros, 1780, Fazenda Experimental Lageado, Botucatu 18610-307, SP, Brazil
}

\section{A R T I C L E I N F O}

\section{Article history:}

Received 13 February 2017

Received in revised form 6 April 2017

Accepted 17 April 2017

Available online 19 April 2017

\section{Keywords:}

Polybia paulista

Wasp venom

-omics-

Peptides

Allergens

Drugs

\begin{abstract}
A B S T R A C T
Polybia paulista (Hymenoptera: Vespidae) is a neotropical social wasp from southeast Brazil. As most social Hymenoptera, venom from $P$. paulista comprises a complex mixture of bioactive toxins ranging from low molecular weight compounds to peptides and proteins. Several efforts have been made to elucidate the molecular composition of the P. paulista venom. Data derived from proteomic, peptidomic and allergomic analyses has enhanced our understanding of the whole envenoming process caused by the insect sting. The combined use of bioinformatics, -omics- and molecular biology tools have allowed the identification, characterization, in vitro synthesis and recombinant expression of several wasp venom toxins. Some of these P. paulista - derived bioactive compounds have been evaluated for the rational design of antivenoms and the improvement of allergy specific diagnosis and immunotherapy. Molecular characterization of crude venom extract has enabled the description and isolation of novel toxins with potential biotechnological applications. Here, we review the different approaches that have been used to unravel the venom composition of $P$. paulista. We also describe the main groups of $P$. paulista - venom toxins currently identified and analyze their potential in the development of component-resolved diagnosis of allergy, and in the rational design of antivenoms and novel bioactive drugs.
\end{abstract}

(c) 2017 Published by Elsevier B.V

\section{Contents}

1. Introduction . . . . . . . . . . . . . . . . . . . . . . . . . . . . . . . . . . . . . . 89

2. Exploring P. paulista venom - omics approaches . . . . . . . . . . . . . . . . . . . . . . . . . . . . . . . . . . . . . . . . . . 90

3. Polybia paulista - venom peptide arsenal. . . . . . . . . . . . . . . . . . . . . . . . . . . . . . . . . . . . . 94

3.1. Mastoparans (Polybia-MP) . . . . . . . . . . . . . . . . . . . . . . . . . . . . . . . . . . . . . . . . . 94

3.2. Chemotactic peptides . . . . . . . . . . . . . . . . . . . . . . . . . . . . . . . . . . . . . 96

4. Polybia paulista venom allergens . . . . . . . . . . . . . . . . . . . . . . . . . . . . . . . . . . . . . . . . . . 96

4.1. Phospholipase A2 (PLA2) . . . . . . . . . . . . . . . . . . . . . . . . . . . . . . . . . . 97

4.2. Phospholipase A1 (Poly p 1). . . . . . . . . . . . . . . . . . . . . . . . . . . . . . . . . . . . . . . . . . . . . . . 97

4.3. Hyaluronidase (Poly p 2) . . . . . . . . . . . . . . . . . . . . . . . . . . . . . . . . . . . . . . . . . . . 98

4.4. Antigen 5 (Poly p 5) . . . . . . . . . . . . . . . . . . . . . . . . . . . . . . . . . . . . . . . 98

5. Potential biotechnological applications . . . . . . . . . . . . . . . . . . . . . . . . . . . . . . . . . . . . . . . . 98

5.1. Antimicrobial and antifungal activity . . . . . . . . . . . . . . . . . . . . . . . . . . . . . . . . . . . . . . . . . 99

Abbreviations: PLA1, phospholipase A1; PLA2, phospholipase A2; Poly p 1, phospholipase A1 from Polybia paulista venom; Poly p 2, hyaluronidase from Polybia paulista venom; Poly p 5 ,

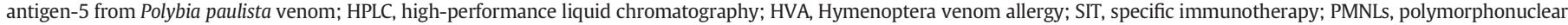
leukocytes; CRD, component resolved diagnosis.

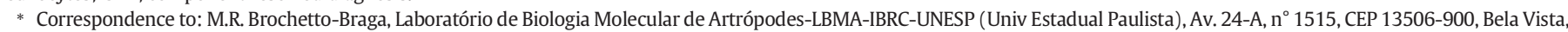
Rio Claro, SP, Brazil.

** Corresponding author.

E-mail addresses: aperezriverol@gmail.com (A. Perez-Riverol), jrbio04@rc.unesp.br (J.R.A. dos Santos-Pinto), alexis.musacchio@cigb.edu.cu (A.M. Lasa), mspalma@rc.unesp.br (M.S. Palma), mrbbraga@rc.unesp.br (M.R. Brochetto-Braga). 


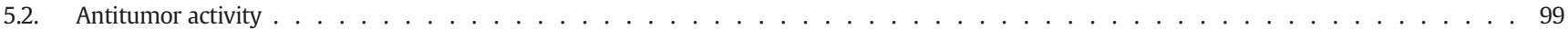

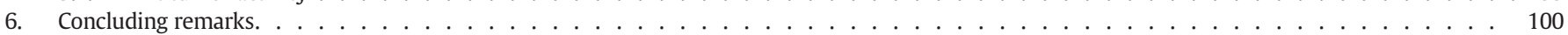

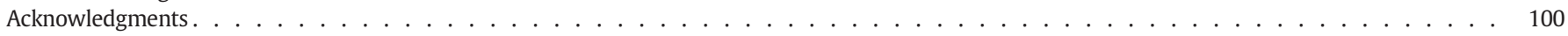

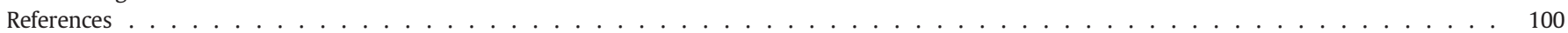

\section{Introduction}

Sting accidents caused by social Hymenoptera represent one of the three major causes of anaphylaxis among human population worldwide [1]. Venoms from these insects are mixtures of unique natural weapons evolved to ensure the defense of the colony against predators and prey capture [2]. Venom toxin cocktails include low molecular weight compounds - terpenes, biogenic amines -, highly abundant peptides, and allergenic proteins - phospholipases A1, A2, hyaluronidases, acid phosphatase and antigen 5 - [3]. Low molecular weight compounds, and peptides are often involved in toxic reactions causing pain, inflammation, tachycardia/bradycardia and cardiac arrhythmia [4]. Meanwhile, allergenic proteins are related to local and/or systemic allergic reactions including life-threatening anaphylaxis related to the occurrence of HVA.

More than 20,000 species of bees (Apoidea) and ants (Formicidae) along with 15,000 species of wasps and yellow jackets (Vespoidea) have been identified as clinically relevant [5]. To date, systemic analyses based on the use of biomolecule databases, bioinformatic tools and -omics- approaches including genomic, transcriptomic, proteomic, peptidomic and glycomics have been successfully used to unravel the toxins arsenal from these venomous animals [6,7]. Venomic analyses of bioactive molecules from social Hymenoptera have enabled the rational design of novel antitoxins [8], and the evaluation of venom components for potential biotechnological applications. Furthermore, detection and molecular characterization of allergenic proteins from Hymenoptera venoms have enabled the production of recombinant allergens then allowing the development of component resolved diagnosis (CRD) and molecular-defined immunotherapy (IT) of HVA [9]. Unlike traditional methods based on the use of crude venom extracts that showed an extremely variable composition [10], these novel alternatives for allergy diagnosis and SIT use defined panels of standardized and highly purified allergens with characterized physiochemical and immunologic profiles. Consequently, the use of recombinant allergens as the allergenic materials significantly improves the reliability of the diagnosis and the safety profile of the immunotherapy [3,7].

Brazil hosts nearly 320 species of social wasps which represent $57 \%$ and 33\% of the species currently described in Latin America (552) and worldwide (974), respectively [11]. The close coexistence between social wasps and the human populations (Fig. 1) causes a high number of medically important stinging accidents, due to the highly aggressive behavior of these insects [12]. The victims may experience local toxic and/or immunological life-threatening reactions, depending on the number of wasps involved in the accident, the amount of venom

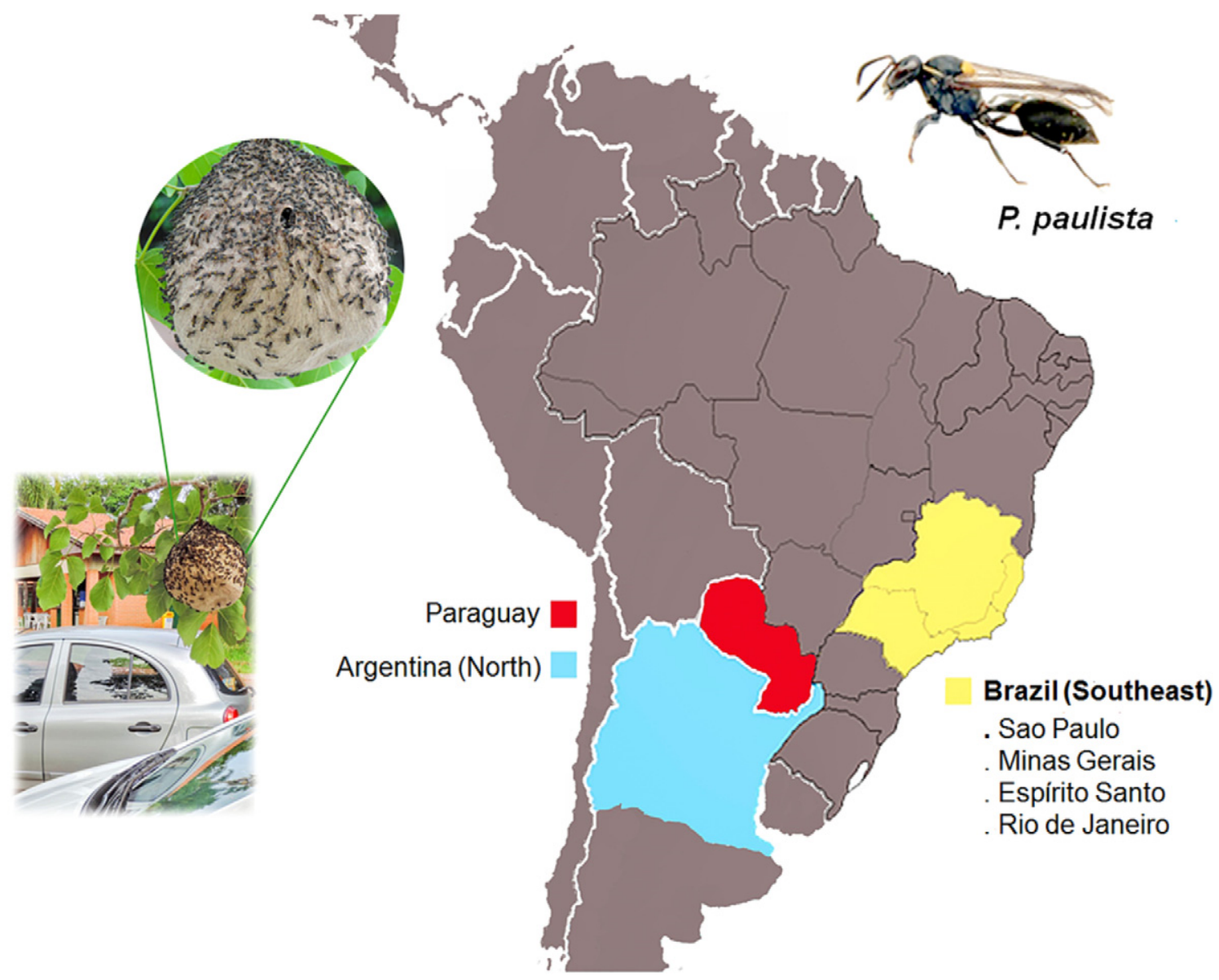

Fig. 1. Distribution of P. paulista wasp in South America. 
injected and the levels of sensitization to venom allergens. Unfortunately, the vast majority of these accidents and the prevalence of HVA have been neglected for decades in Brazil as a consequence of the lack of data collected by health institutions and survey analyses. The World Health Organization (WHO) considered the accidents of envenoming caused by venomous animals (snakes, spiders, scorpions, wasps, ants and bees) as a neglected public health issue in the developing countries [13]; this was latter recognized by the Brazilian Academy of Sciences [14].

Epidemiological studies have estimated that $56.6 \%-94.5 \%$ of human populations have been stung by Hymenoptera, at least once in lifetime [15]. The prevalence of systemic allergic reactions related to HVA is $0.3-8.9 \%$, with anaphylaxis occurring in $0.3-42.8 \%$ of the cases [1]. The prevalence of the accidents caused by insects sting have been predicted to be higher in developing and low-income countries since a higher percentages of humans develop their economic activities near to populations of Hymenoptera insects [16]. All these data strongly suggest that Hymenoptera stings and Hymenoptera venom anaphylaxis are outstanding human health problems not only in Brazil, but also in whole Latin America. This is particularly true for social wasps considering the remarkable diversity of species currently identified in the country cohabitating with humans. Moreover, at least one epidemiologic study conducted with Brazilian patients $(n=138)$ showed that wasp venom was the main cause of HVA in the population analyzed [17].

The epidemiological data currently available suggest that 10 to 15 thousands sting accidents related to bees and/or wasps occur annually in Brazil. Most of these are caused by Polybia paulista (Hymenoptera: Vespidae) with 35-42 deaths registered every year [18,19]. P. paulista -popularly known as "paulistinha"- is a clinically relevant neotropical wasp that belongs to the Polistinae subfamily which is divided in four tribes (Ropalidiini, Polistini, Epiponini and Mischocyttarini) [20]. Several studies showed that the species from Epiponini tribe are the most commonly founded in Southeast Brazil [11]. Moreover, members of the Polybia group -including P. paulista- have been reported as the most abundant species founded in urban garden from this region (Fig. 1) [21]. As a consequence, $P$. paulista-related sting accidents and venom allergy are highly frequent, and represent major causes of human morbidity in Southeast Brazil.

Considering these facts, $P$. paulista have been extensively studied, and became a model for proteomic, peptidomic, immunological and pharmacological studies in insect venom toxinology during the last two decades. Several efforts have been made to explore and profile the toxin arsenal of this endemic wasp as a prerequisite to develop antivenoms and to treat $P$. paulista-related toxic and allergic reactions.

Early attempts to elucidate the venom composition of this wasp were based on the use of low-resolution chromatographic methods, which were able to detect a limited number of toxins [22]. Nevertheless, recent studies $[23,24]$ performed using more resolutive proteomic and peptidomic techniques have promoted a systemic comprehension of crude venom extract composition. The elucidation of $P$. paulista-toxins arsenal allows us to hypothesize about a general envenoming mechanism [23].

It has been informed that peptides comprise up to $70 \%$ of the weight of freeze-dried venom in social Hymenoptera [2]. The use of highthroughput techniques have boosted the identification of frequent as well as rare venom peptides generating a large quantity of data related to venom composition [25]. Thousands of venom peptides from snake [26,27], spider [28,29], scorpion [30], marine snails [31] and solitary/social Hymenoptera [32,33] have been detected and described after the implementation of these approaches. In the case of $P$. paulista venom, the use of peptidomic analyses resulted in the description and further molecular characterization of known and also novel wasp-venom peptides $[24,34]$. The peptides toxins characterized in P. paulista displayed diverse structural features and biological activities revealing the complexity of toxins arsenal produced by this social wasp.
Despite the great diversity of social Hymenoptera identified in Brazil, no component-defined allergenic materials are available for specific diagnosis of allergy [12,35]. Currently, HVA diagnosis is based on the use of crude venom extracts from native species or commercialized allergens from insects of Northern Hemisphere. The use of crude venoms increases the incidence of cross-reactivity due to the presence of crossreactive carbohydrate determinants (CCDs) [36]. Meanwhile, diagnosis of Brazilian patients conducted with allergens from species of temperate regions lead to a decrease in sensibility and miss-identification of the culprit venom thus compromising the efficacy and safety profile of the specific immunotherapy (SIT). Inclusion of non-relevant allergens in immunotherapy leads to non-specific sensitization of patients and can cause life-threatening systemic side-effects [37]. The incidence of adverse side effects worldwide during immunotherapy has been estimated in $25.1 \%$ and $5.8 \%$ for honeybee and vespid venoms, respectively [38]. Overall, these facts set significantly challenges for the aim of decreasing the morbidity related sting accidents and HVA in Brazil.

Venomic analyses represent a powerful approach to face these challenges as they provide systemic information about the proteinaceous components comprised in social Hymenoptera venoms, including allergens. To date, more than 60 Hymenoptera venom allergens have been identified, cloned, heterologously expressed and are currently being tested [3] allowing the design of panels of recombinant allergens that can be used in allergy CRD and molecular-defined SIT. Proteomic analysis allowed the identification and purification of the three major allergens from P. paulista venom: phospholipase A1 (Poly p 1) [39], hyaluronidase (Poly p 2) [40,41] and antigen 5 (Poly p 5) [42]. These allergens are medium (Poly p 2) to highly abundant (Poly p 1 and Poly p 5 ) venom proteins $[23,35,39,41,43]$. The combined use of bioinformatics and proteomic tools as well as molecular biology techniques resulted in the cloning, sequencing and further heterologous expression in $E$. coli of both Poly p 1 [35] and Poly p 2 [12]. Also, nPoly p 5 is currently evaluated for the development of a peptide-based allergy diagnoses system and an engineered vaccine [44]. Both strategies could significantly improve the diagnosis and treatment of $P$. paulista venom allergy and then the patient's quality of life.

Finally, venomic-based uncovering of $P$. paulista-toxins arsenal has allowed the description of diverse pharmacological activities that could be evaluated for either development of antivenoms or novel biotechnological applications $[45,46]$ (Fig. 2). Here, we review the main approaches used for systemic molecular profiling of $P$. paulista venom composition. Additionally, we describe the growing body of data related to the identification and functional characterization of bioactive molecules comprised in the venom of this wasp. We focus on the production of recombinant allergens toward improvement of the strategies currently used for specific diagnosis and treatment of allergy. Also, we discuss the potential use of P. paulista-venom toxins for the rational design of antivenoms and the development of novel biopharmaceuticals products.

\section{Exploring $P$. paulista venom - omics approaches}

Animal venoms comprise heterogeneous levels of low molecular weight compounds, peptides and proteins, ranging from high to almost undetectable concentrations. The heterogeneity of toxin levels represented a significant challenge for venom characterization. Low-abundance molecules remained undescribed for decades thus tackling our systemic comprehension of the envenoming process. Proteomic and peptidomic analyses based on the use of techniques such as LC-ESIMS and nano-ESI-MS/MS have progressively reversed this situation enabling identification of thousands of novel venom proteins and peptides $[24,47,48]$.

To date, $P$. paulista venom has been explored using mainly peptidomic, proteomic and allergomic approaches (Fig. 2). Early efforts to elucidate $P$. paulista-venom peptides composition were conducted using classical procedures directed to the identification and molecular 


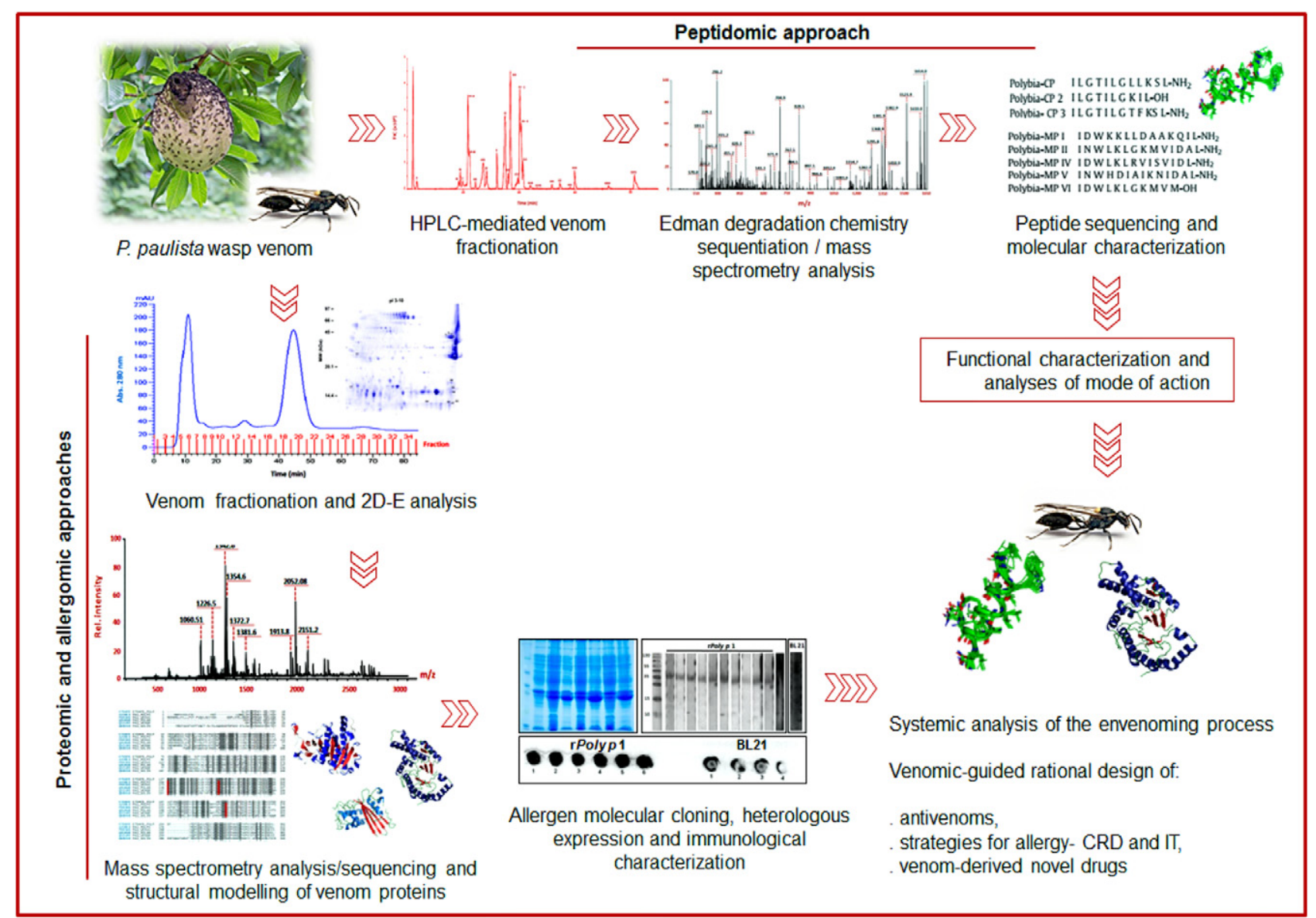

Fig. 2. Overview on the workflow used for the venomic analyses of $P$. paulista

characterization of a limited number of these molecules. The combined use of HPLC with mass spectrometry techniques (MALDI-Tof-PSD-MS and QTof-MS/MS) [49,50] resulted in the identification of two new peptides that are related to a subclass of mastoparan toxins. Both toxins showed a potent hemolytic activity, induced mast cells degranulation and were predicted to induce inflammation during envenoming process. Two low molecular weight peptides named Polybine-I and -II, that are also related to inflammation and chemotaxis of PLMNs were isolated using reverse phase-HPLC, sequenced using ESI-MS/MS and functionally characterized [51]. Another two peptides, Polybia-MPI and Polybia-CP with antibacterial and chemotactic activity, were described using a similar procedure [52].

Likewise to the identification of peptides, early attempts to describe proteinaceous components in $P$. paulista venom were conducted using traditional proteomic procedures. For instance, a gel filtration chromatography -Sephadex G 200- followed by ion exchange chromatography -DEAE Cellulose- enabled purification of Polybitoxins, a group of glycosylated phospholipases A2 [22]. Polybitoxins showed a high hemolytic activity in functional characterization bioassays. The native form of Poly p 1 (nPoly p 1 ) was initially isolated and characterized using a similar proteomic approach based on a double-step chromatographic purification protocol followed by Edmand degradation chemistry sequentiation [39]. The nPoly p 2 was purified using a single step ionexchange chromatography, sequenced by mass spectrometry and, as nPoly p 1, structural modeled using several bioinformatics tools and protein structure databases $[40,41]$. Non proteinaceous or peptidic compounds such as Polybioside I, a low molecular weight neuroactive toxin was also described after analyses of $P$. paulista venom using a classical fractionation procedure [53].
The approaches described above ensured an accurate detection and molecular characterization of some paulistinha toxins. Nonetheless, its application reduced the possibility to obtain a systemic picture of $P$. paulista venom composition as a limited number of bioactive molecules have been identified and described in each study. To cope with this, some proteomics and peptidomic techniques that allowed detection of a large number of high, but also low-abundance, venom toxins has been performed recently. A proteome profile was obtained after submitted the $P$. paulista crude venom extract to bi-dimensional electrophoresis (2-DE) followed by identification of digested individual spots using matrix-assisted laser desorption ionization time-of-flight/time of-flight-mass spectrometry (MALDI TOF/TOF-MS/MS) [23].

The 2 -DE revealed $237 \pm 36$ spots (five replicates) with MW ranging from 8 to $96 \mathrm{kDa}$ and $\mathrm{pH}$ values from 3 to 10 (Fig. 3). Further mass spectrometry analysis resulted in identification of 84 venom proteins related to 12 different molecular functions. Proteins from the venom glands were classified into three different groups: typical venom proteins, muscle proteins and housekeeping proteins. The first group included 53 components, 23 similar to social wasp venom proteins previously described, most related to allergenicity. An immunoblotting analysis showed that 16 single proteins immunoreacted with sera from $P$. paulista venom-allergic patients (Fig. 3 ) revealing the potential of several venom toxins, and not only the three major allergens mentioned above, to be evaluated for improvement of CRD. Furthermore, this study showed for the first time the presence of antigen 5 and diverse metalloproteases as P. paulista venom components. As the authors mentioned [23], the discovery of novels allergenic proteins will greatly improve our understanding of the pathophysiological effects experienced by the victims after the wasp sting. 


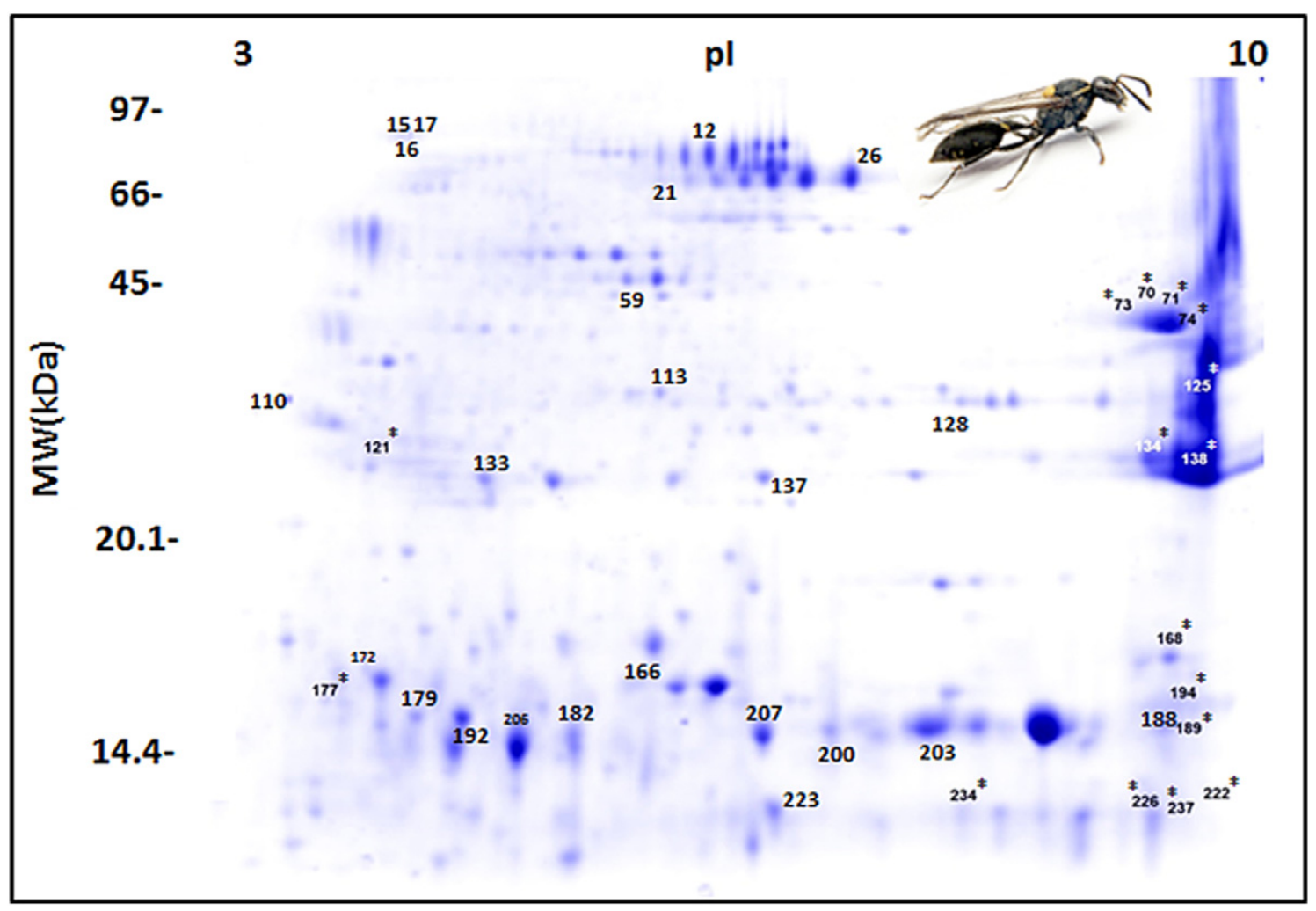

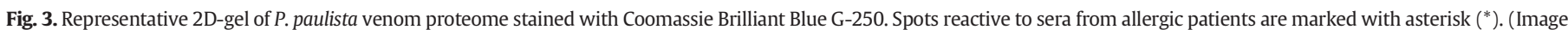
corresponds to a replicate of the experiment originally published by dos Santos et al. (2010)).

Venom proteome profiling of $P$. paulista has also allowed the description of a general mechanism for the envenoming process (Fig. 4) based on the different functions described for the identified proteins [23]. However, it is important to note that only $84 / 236$ spots $(\sim 35 \%)$ were assigned with a putative protein function. The relative low number of identified spots is related to the limitations of the bottom-up gel based approach used in this study, as low-abundance proteins are difficult to identify $[55,56]$. Also, the large number of Hymenoptera proteins with unknown functions deposited in databases when the analysis was conducted hampered the identification of other venom toxins [57, 58]. A reanalysis of the venom proteome of $P$. paulista using a gel-free shotgun proteomic approach combined with the use of updated protein databases could significantly enhance the identification of wasp venom toxins $[48,64]$ with relevant biological functions. The use of this sensitive analytical alternative will allow the identification of the low-abundance "hidden proteins" in P. paulista venom thus helping to complete the model proposed for the envenoming process [48]. Proteinaceous compounds identified using shotgun proteomics could be also evaluated for the development of novel drugs with potential pharmaceutical applications.

For decades, the peptidome from $P$. paulista venom remained poorly explored. Before the application of high throughput screening approaches only few bioactives peptides were chemically characterized in the venom of this wasp $[49,59,60]$. Nonetheless, the use of advanced mass spectrometry techniques significantly changed that landscape and resulted in the description of dozens of novel $P$. paulista venom peptides [24]. An intra- and inter-colonial analysis of peptide diversity in $P$. paulista venom performed using LC-ESI-MS showed high levels of variability for both conditions. In the intra-colonial analysis (venom collected from one nest at three different seasons) a total of 146 peptides were detected. Interestingly, from that number only 44 (30\%) peptides were common among the three samples. Similarly, from a total of 179 peptides detected in the inter-colonial analysis (venom collected from three different nests at the same time), only 36 (20\%) were common across the three nests [34]. As the authors stated during discussion of these results, the high number of peptides in combination with the intra- and inter-colonial variations in the venom peptides' composition might extends the spectrum of predators/preys against these toxins may be effective.

Interestingly, similar variations in other venomous animals have been suggested to correlate with differences in the pharmacological effects of the venom. For instance, intra-specific variability in Conus vexillum venom composition correlated with variations on venom potency and cytotoxic effects [61]. Furthermore, a systemic venomic analysis involving sixteen species of snakes from Costa Rica has showed a profound diversity on venom composition [27]. The analyses of the snake venom-proteome/peptidome profiles have helped to partially explain and even predict the potential variations on the pharmacological and pathophysiological effects suffered by the victims. The diversity in clinical symptoms caused by $P$. paulista venom is mainly related to allergenic proteins $[23,62]$. Despite the diversity of pharmacological activities suggested for $P$. paulista venom peptides [2], it is difficult to correlate intra/inter-colonial variations in $P$. paulista venom peptidome with differences in clinical manifestations as peptide activities is often related to limited number local toxic reactions [24]. However, a similar analysis for exploring the intra/inter variability on the $P$. paulista-venom proteome, including other medically relevant neotropical Hymenoptera could be extremely helpful for understand differences in clinical manifestations, particularly in the case HVA [60]. In fact, it has been informed that the frequency and intensity of the venom-caused allergic reactions may vary not only as a consequence of intra-individual variations along the victims, but also, along the qualitative and quantitative composition of the insect venoms [48,65].

A peptidome profile of $P$. paulista venom was recently obtained using a reversed-phase chromatography coupled to electrospray ionization-ion trap-time of flight mass spectrometry (LC-ESI-IT-TOF/MS) [24]. The profiling included peptides detection, sequencing, in vitro synthesis and biological evaluation. In summary, fourteen unambiguous peptide 


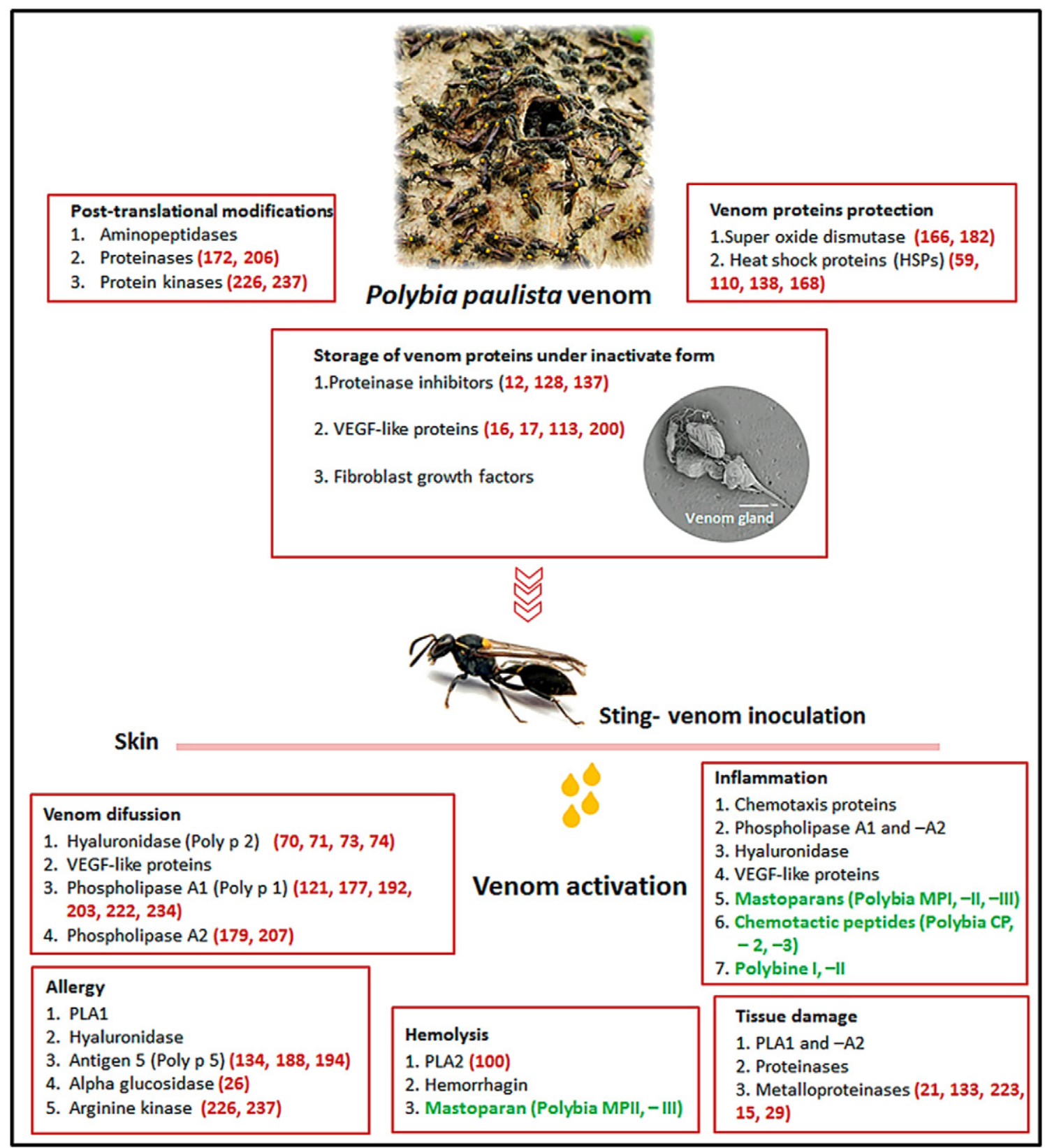

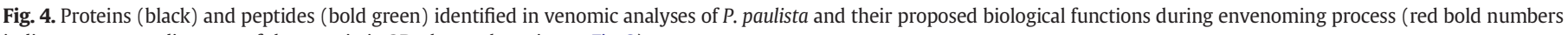
indicate corresponding spot of the protein in 2D-electrophoresis, see Fig. 3).

sequences were assigned. From that group, nine represented novel peptides including two wasp kinins, two chemotactic components, three mastoparans and two with unknown function. The peptides were further synthesized on solid-phase and submitted to different bioassays. Analysis of biological activity showed that P. paulista kinins (i.e. - Thr ${ }^{6}$ Bradykinin, RA-Thr ${ }^{6}$-Bradykinin, RA-Thr ${ }^{6}$-BradykininDT) caused weak mast cell degranulation, oedema formation and pain suggesting that the toxins are used as a defense weapon causing discomfort in natural predators. Meanwhile, the novel peptides Polybia-CP 2 and Polybia-CP 3 promoted a medium to strong chemotaxis of polymorphonuclear leukocytes (PMNLs). Finally, as previously characterized $P$. paulista venom mastoparan, novels Polybia-MP IV, V and IV are related to inflammation during envenoming process.

Using a proteometabolomic approach, Esteves et al. (2017) [66] identified several volatiles compounds (as metabolites), such as tetradecanol, tridecanoic acid, tetradecanoic acid, tetradecanoic acid methyl ester, hexadecanoic acid methyl ester, octadecanol, octadecanoic acid, eicosanoic acid and eicosanoic acid methyl ester in the Polybia paulista venom. The authors suggested that these compounds are produced by Dufour's gland and secreted/mixed into the venom reservoir for use as alarm pheromones in a coordinated colony defense, including a massive attack against the predators. Dufour's gland and the venom gland are associated with the sting apparatus in female aculeate wasps and bees; despite this, no role have been attributed to the former in terms of venom activity [67].

The peptidome and proteome profiling of the P. paulista venom have contributed to hypothesize about a general mechanism for envenoming process caused by insect sting [23]. The mechanism proposed (Fig. 4) includes proteins and/or peptides involved in venom production, protection and storage in the venom gland and reservoirs along with those acting after the inoculation on the victim/prey. The actions of the toxins during the envenoming process have been divided into five basic 
functions: venom diffusion, hemolysis, tissue damage, inflammation and allergy.

A more detailed analysis of the proposed mechanism suggests that, similar to other venom hyaluronidases [68-72], Poly p 2 could acts as a spreading factor that facilitates venom diffusion from the site of the inoculation. Hyaluronidases cleave the hyaluronan, a polysaccharide of the extracellular matrix found in connective tissue $[40,69]$. Degradation of hyaluronan potentiates the action of the venom by facilitating the toxins diffusion into the blood stream and the tissues of the victim $[68,69,73,74]$. In fact, hyaluronidases are widely distributed in animal venoms $[70,75]$ highlighting the important role of these enzymes during the envenoming process. The Poly $\mathrm{p} 2$, which showed a significant enzymatic activity in vitro [40] and structural homology with other Hymenoptera venom hyaluronidases described as spreading factors $[41,72]$, has been proposed to increase the absorption rates and diffusion of the P. paulista venom into tissues after the insect sting [40]. The development of antivenoms or inhibitors that target this hyaluronidase could limit the diffusion of the venom thus preventing or delaying the occurrence of large tissue damages $[70,71]$, potentially allowing a more efficient clinical management of the victim.

Despite that $P$. paulista has showed a potent hemolytic activity, intravascular hemolysis is rarely induced by insect stings. This pathophysiological manifestation has been informed mainly in veterinary accidents caused by snakes [76]. However, hemolysis has been occasionally described in massive attacks involving honeybees or wasps [23,77]. Hemolytic activity of $P$. paulista venom is related to peptides mastoparan II, III [60] and PLA2s [22]. In vitro assays have showed that both groups of toxins are direct hemolytic factors that disrupt the integrity of erythrocyte plasma membrane in the absence of any other agent $[22,60]$. As suggested for other venom hemolytic toxins such as mellitin [78], cardiotoxins [79] and venom snake PLA2s [76], the identification of these $P$. paulista venom toxins could be helpful for the analysis and further understand of pathophysiology effects caused by the wasp sting. Interestingly, at least one study [80] has showed that the activity of a PLA2 from the venom of a rattlesnake (Crotalus durissus terrificus) is facilitated by the activity of the snake hyaluronidase. A similar mechanism for enhancement of PLA2 activity could be proposed in the case of $P$. paulista venom.

Identification of snake venom-like metalloproteases (spots 21, 133 in Fig. 3) in P. paulista could represent a key finding to explain some symptoms experienced by the victims during envenomation caused by the wasp [23]. The activity of some snake-venom metalloproteases cause myonecrosis, skin damage, edema, and inflammatory reactions [81] in the victims which are clinical manifestations that have been informed in wasps' massive attacks [82]. Moreover, snake venom-like zinc-metalloproteinase-disintegrins also identified in P. paulista (spot 15 in Fig. 3) are known to cause hemorrhage, platelet aggregation, and some types of coagulopathies [83], which are clinical effects that have also been observed in victims of accidents involving multiple insect stings [23]. Structural and functional analysis must be performed to elucidate to role of $P$. paulista venom metalloproteases in the envenoming process [23]. As suggested for hyaluronidase, the production of metalloprotease antivenoms and the rational design of inhibitors could help to prevent the effects of these toxins after a $P$. paulista massive attack.

Besides these metalloproteases, $P$. paulista venom phospholipases $\mathrm{A} 1$ and $\mathrm{A} 2$ has been proposed to cause tissue damage. These enzymes disrupt phospholipidic packing of cellular membranes and are known to exert a wide diversity of toxic and pharmacological reactions. Venom PLA2s activity could produce edematogenic, hypotensive, cytotoxic and anticoagulant effects in the victims [84]. Meanwhile, some wasp PLA1s have showed a potent hemolytic activity [85] although their major consequence during envenoming is the induction of allergic reactions [35]. The role of these $P$. paulista venom toxins along with those involved in inflammation (mastoparans Polybia MPI, II, III, Polybia
$\mathrm{CP}, 2,3$ ) and allergic reactions (Poly p 1, 2 and 5) mentioned in the proposed mechanism of envenoming will be addressed later in this review.

Overall the profiling of $P$. paulista venom composition using traditional and/or faster and more sensitive analytical techniques has rendered the identification of dozens of novel proteins and peptides [23, $24]$. Similar to other venomous animals $[27,86]$, the wasp venomic analyses have expanded our knowledge about the arsenal of toxins produced by this social Hymenoptera. The venom composition suggests that the insect sting triggers a complex pathological scenario and that during the envenomation a wide range of molecular or/and cellular mechanisms are targeted by the wasp toxins. Further studies on these mechanisms will pave the way for the development of novel antivenoms and the design of specific immunotherapy strategies for induces venom tolerance in allergic patients [87]. Moreover, reanalysis of P. paulista venom using more sensitive analytical techniques and Hymenoptera protein databases currently available could increase the number of proteins identified thus helping to enlarge the panel of described venom composition and increase our understanding of the envenomation.

A transcriptome analysis of the $P$. paulista venom glands could also be used for exploring the toxin arsenal of the wasp. Transcriptome profiling provides large amounts of biological information and represent a feasible alternative to mine novel compounds in animal venoms [88, 89]. As in the case of solitary [90] and other social Hymenoptera species [91,92], P. paulista venom-transcriptome profiling could significantly increases the number of toxins identified then allowing its structural and functional characterization. Consequently, the data derived for transcriptome analysis could help in the full decoding of the P. paulista venom composition and the pathophysiological caused by the insect sting.

\section{Polybia paulista - venom peptide arsenal}

As mentioned, the use of traditional venom fractioning approaches and second-generation sequencing techniques allowed the identification of several peptides comprised in paulistinha venom. Evaluation of biological activities of these toxins is a milestone for the understanding of it functions during envenoming and the further design of antivenoms. In the next two sections we describe the main groups of peptides (Fig. 5) currently identified in P. paulista venom and its biological activity. These findings are also summarized in Table 1.

\subsection{Mastoparans (Polybia-MP)}

Mastoparans are membrane-active polycationic molecules of 12-14 amino acids residues that represent the most abundant class of peptides in venom from both solitary and social hunting wasps [93]. These toxins caused histamine release from mast cells, serotonin from platelets along with catecholamines and adenylic acids from adrenal chromaffin cells. Mechanism of action involved either insertion in cell membrane, pore formation lately causing cell surface disruption and lysis; or direct interaction with $G$ proteins on the cytoplasmatic face, thereby perturbing transmembrane signaling [94].

Two mastoparans, described as linear tetra-decapeptides of 1612.07 and $1658.60 \mathrm{Da}$. were the first group of peptides identified in $P$. paulista venom [49]. The analysis of the peptides primary sequence revealed that both toxins are similar to previously described mastoparans. In functional characterization bioassays both peptide showed a potent chemotactic activity as $90 \%$ of rat PMNL cells were chemo-attracted in the presence of each peptide. The toxins also showed a strong hemolytic activity causing in vitro disruption of $100 \%$ of rat red blood cells and also induced degranulation of mast cells.

Polybia-MPI is a typical mastoparan tetra-decapeptide of $1654.09 \mathrm{Da}$ that caused lysis of mast cells, and shows chemotaxis to PMNLs. Unlike the two mastoparans previously described, Polybia-MPI does not have hemolytic activity in rat erythrocytes. A multiple alignment analysis 


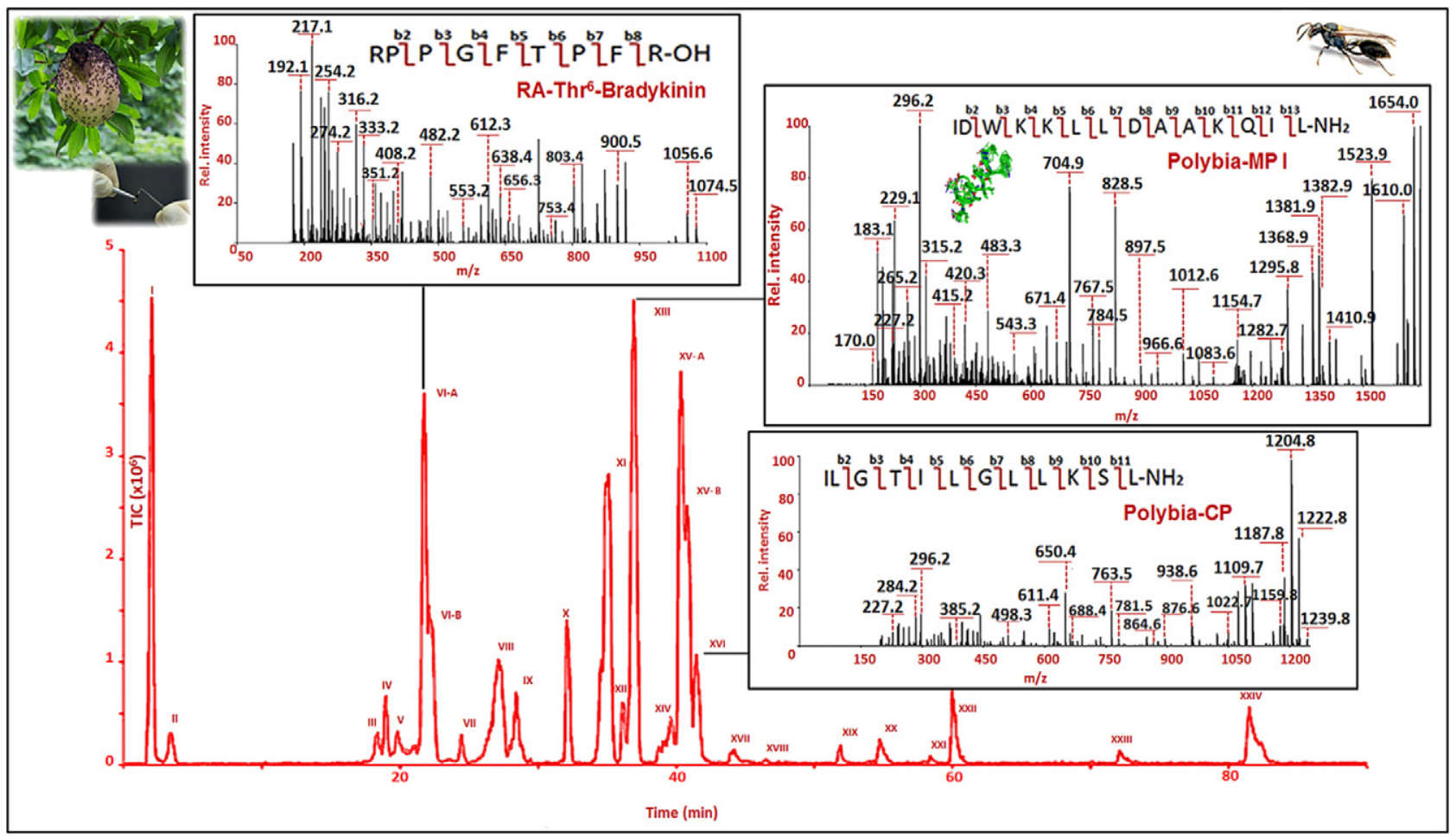

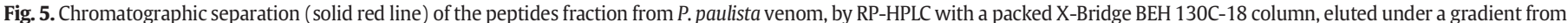

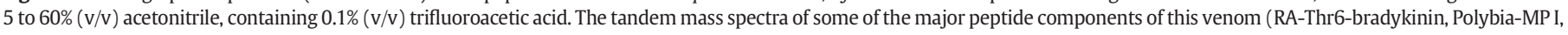
and Polybia-CP) are also shown. (Modified with permission from Dias et al., 2015).

showed different levels of identity with primary sequence of mastoparans from venom of other social wasps, with the higher homology $(71 \%)$ related to the mastoparans identified in Protonectarina sylveirae venom [95]. Polybia-MPI also displayed a potent antimicrobial activity against Gram-positive and Gram-negative bacteria. In the case of $B$. subtilis $(\mathrm{Gram} /+)$ and $P$. aeruginosa $(\mathrm{Gram} /-)$ the minimum

Table 1

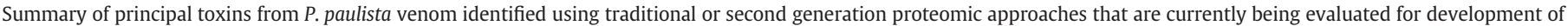
antivenoms, CRD and IT of allergy and novel drugs.

\begin{tabular}{|c|c|c|c|}
\hline \multicolumn{4}{|l|}{ P. paulista venom toxins } \\
\hline Type of molecule & Sequence & Biological activity/applications & References \\
\hline \multicolumn{4}{|l|}{ Peptides } \\
\hline \multicolumn{4}{|l|}{ Chemotactic } \\
\hline Polybia-CP & CP I L G T I L G L L K S L-NH & $\begin{array}{l}\text { Chemotaxis of PMNLs, antimicrobial and antifungal/development of antimicrobial, antifungal } \\
\text { and antitumor drugs }\end{array}$ & de Souza et al., 2005 \\
\hline Polybia-CP 2 & I L G T I L G K I L-OH & & Dias et al., 2015 \\
\hline Polybia-CP 3 & I L G T I L G T F KS L-NH ${ }_{2}$ & & \\
\hline Protonectin (1-6) & I L G T I L-OH & & Mendes et al., 2004 \\
\hline \multicolumn{4}{|l|}{ Mastoparans } \\
\hline Polybia-MP I & $\begin{array}{l}\text { I D W K K L L D A A K Q I } \\
{\mathrm{L}-\mathrm{NH}_{2}}\end{array}$ & $\begin{array}{l}\text { Mast cell degranulation, antibacterial and antifungal/development of antimicrobial, antifungal } \\
\text { and antitumor drugs }\end{array}$ & de Souza et al., 2005 \\
\hline Polybia-MP II & $\begin{array}{l}\text { I N W L K L G K M V I D A } \\
\text { L-NH }\end{array}$ & & de Souza et al., 2009 \\
\hline Polybia-MP III & $\begin{array}{l}\text { I N W L K L G K M V M D V L } \\
-\mathrm{NH}_{2}\end{array}$ & & \\
\hline Polybia-MP IV & $\begin{array}{l}\text { I D W L K L R V I S V I D } \\
\text { L-NH }\end{array}$ & & \\
\hline Polybia-MP V & $\begin{array}{l}\text { I N W H D I A I K N I D A } \\
\text { L-NH } \mathrm{N}_{2}\end{array}$ & & Dias et al., 2015 \\
\hline Polybia-MP VI & I D W L K L G K M V M-OH & & \\
\hline Proteins & $\begin{array}{l}\text { Accesion number/entry } \\
\text { name }\end{array}$ & & \\
\hline $\begin{array}{l}\text { Phospholipase A1 } \\
\text { (Poly p 1) }\end{array}$ & A2VBC4/PA1_POLPI & Allergen-hemolytic/CRD and molecular-based IT & Santos et al., 2007 \\
\hline $\begin{array}{l}\text { Hyaluronidase (Poly p } \\
\text { 2) }\end{array}$ & $\begin{array}{l}\text { P86687/HUGA_POLPI } \\
\text { E0AD89/E0AD89_POLPI }\end{array}$ & Allergen-Venom diffusion/CRD and molecular-based IT & $\begin{array}{l}\text { Pinto et al., } 2012 \\
\text { Justo-Jacomini et al., } \\
2013\end{array}$ \\
\hline Antigen 5 (Poly p 5) & P86686/VA5_POLPI & Allergen-Unknown/CRD and molecular-based IT & $\begin{array}{l}\text { dos Santos-Pinto et al., } \\
2014\end{array}$ \\
\hline
\end{tabular}


inhibitory concentration (MIC) values were lower than those obtained for Tetracycline (positive control).

The in silico prediction of the Polybia-MPI secondary structure revealed the presence of about $71.43 \%$ of $\alpha$-helix conformation and $28.57 \%$ of coil structure. The high content of $\alpha$-helix in Polybia-MPI could be mediating the peptide interaction with cell membrane then promoting antimicrobial activity. Further analysis for characterization of the peptide interaction with bacterial membranes and cell wall could aid in the development of antibiotics based in Polybia-MPI, as predicted for other antimicrobial peptides (AMPs) [96].

Similar to Polybia-MPI, Polybia-MP-II and -MP-III were identified using a traditional peptidomic approach [60]. The chromatographic profile obtained after HPLC-mediated fractionation of $P$. paulista venom showed 13 peaks, with these peptides contained in the last fraction (F13). Further separation of this fraction followed by Edmand degradation chemistry and MS/MS analysis enabled the sequencing of both toxins. Circular dichroism analysis of Polybia-MP-II for secondary structure determination showed an $\alpha$-helical and $\beta$-sheet content of 30 and $20 \%$, respectively. Meanwhile, Polybia-MP-III has an $\alpha$-helical and $\beta$ sheet content of 24 and 34\%. Considering physiological concentrations of both venom peptides and results derived from functional characterization assays, Polybia-MP-II and -III were proposed to cause mast cell lysis disruption but no significant degranulation during envenoming process. Similarly, the mastoparans showed hemolytic $\left(\mathrm{ED}_{50}=5\right.$ $\times 10^{-5} \mathrm{M}$ ) but not chemotactic activity at physiological conditions. In antimicrobial activity evaluation the two peptides inhibited growth of Gram (+) and Gram (-) bacteria. As expected, given the $\alpha$-helical content in peptides secondary structure, Polybia-MP-II showed the lower $\mathrm{IC}_{50}$ values.

Diverse bioassays for functional characterization of Polybia-MP II showed that it causes sarcolemma disruption, cytoskeleton degradation, mitochondrial damage and has mytotoxic activity $[97,98]$. Further biological activity evaluation showed that the mastoparan causes myonecrosis, inflammation and apoptosis in muscle cells [99]. The mechanism of action includes mitochondrial damage related to potent mitochondrial permeability transition, activation of caspase 3, 9 and induction of TNF- $\alpha$, IFN- $\gamma$, CD68 and CD163.

The levels and diversity of biological activities described for mastoparan peptides in Hymenoptera venoms show that they are key players during the envenoming process. Mastoparans induce secretion of histamine from mast cells, oedema formation that causes pain, toxin reactions and a remarkable physiological discomfort in predators. The detection and molecular characterization of this group of peptides partially explain several symptoms experienced by victim after $P$. paulista sting. Structural and functional data derived from proteomic analysis and bioassays described here may help to design antivenoms to counteract the toxic effects caused by these toxins. Furthermore, $P$. paulista-mastoparans, particularly Polybia-MP-I, could be used for the development of novel antimicrobial drugs.

\subsection{Chemotactic peptides}

Wasp venom chemotactic peptides are involved in massive recruitment of PMNLs followed by the release of large amounts of oxygen peroxide near to the site of sting [2]. The resulting hyperoxidative environment induces local inflammatory responses, cell death and pain. Polybine-I and -II were the first P. paulista venom peptides described with active PMNLs chemoattractant activity [51]. The toxins have an acetylated blocked N-terminus, showed by the inability to interact with the phenylisothiocyanate reagent in Edmand degradation chemistry. In bioassays, the native-acetylated form of the peptides showed higher PMNLs chemoattractant activity than the synthetized, non-acetylated variants.

Polybia-CP is a chemopeptide of 1239.73 Da that, unlike Polybine-I and -II, has a non-blocked N-terminus. Also, unlike chemopeptides described in wasp venom from species of temperate regions (13), Polybia-CP has 12 amino acid residues and lacked a characteristic FLP

tripeptide at the amino terminal side [59]. The duo-decapeptide induced no degranulation in mast cells and presented no hemolytic activity at physiological concentrations. By contrast, Polybia-CP showed high levels of chemotaxis of PMNLs cells $\left(1.7 \times 10^{4}\right.$ cells $\left./ \mathrm{mL}\right)$ at concentration of $10^{-5} \mathrm{M}$. Polybia-CP inhibited Gram positive bacterial growth with $\mathrm{MIC}$ values $=15 \mu \mathrm{g} / \mathrm{mL}$ for both $B$. subtilis and S. aereus. As discussed later in this review, several animal venoms has recently showed remarkably antibacterial activity and as a consequence venoms are gained attention as a suitable source of novel antibiotics [100].

As noted, in a systemic peptidomic analysis of $P$. paulista venom another two chemotactic peptides (Polybia-CP 2 and Polybia-CP 3) were described [24]. Both molecules are typical duo-decapeptides often identified in venom of wasps from neotropical regions [63]. They belong to the group of chemopeptides that contains a single $\mathrm{K}$ residue between positions 8 and 10 in the primary sequence. In the same study, a second group of chemotactic peptides (Protonectin 1-6), previously described in the social wasps Agelaia pallipes pallipes [59,101], was also detected and sequenced. These protonectin-like toxins are small chemotactic peptides - 4 to 8 amino acids residues - obtained as a consequence of serine protease-mediated proteolysis of mastoparans. Protonectins are involved in regulation of leukocytes chemoattraction during envenoming process [24].

The mechanism of action of chemotactic peptides from $P$. paulista remains unknown. However, it has been postulated that chemoattraction of leukocytes induced by these toxins is mediated by the interaction with G-protein coupled receptors (GPCRs) in the cell membrane [59]. G-protein-coupled receptors are a family of ubiquitous proteins with 7 transmembrane domains involved in a large range of pathological process [102]. The direct interaction between GPCRs and the peptides activates a cascade of molecular events resulting in cell migration to the sting site. Thus, Polybia-CP, -CP 2 and -CP 3 could be acting in envenoming process by eliciting massive leucocytes-cell migration and promoting a potent pro-inflammatory response.

\section{Polybia paulista venom allergens}

HVA is the most common cause of life-threatening outcomes after a Hymenoptera sting [5]. It is a classical IgE-mediated allergic disease triggered by the binding of allergen-specific IgE to their own receptors (FceRI) at the surface of mast cells and basophils [43]. The subsequent re-exposure to venom allergens induces degranulation of mast cells and basophils and the release of inflammation mediators such as histamine, leukotrienes, and several cytokines. Mediators release causes type-1 hypersensitivity allergic reactions with symptoms ranging from generalized urticaria, angioedema, blood pressure fall to broncospasms, cardiac and respiratory arrest, and anaphylactic shock [87,103].

To date, the molecular basis of the variations in the susceptibility to Hymenoptera venoms and the symptoms experienced by the victims after the insect sting remain unclear. In atopic patients a genetic predisposition that increases production and/or persistence of allergen-specific IgE and consequently the incidence of HVA has been proposed [15]. Typically, in non-responsive individuals the IgE levels transiently rise after a sting and then return to basal values during the next 1-3 months $[15,104]$. For this group of victims a mechanism of peripheral tolerance development mediated by the regulatory $\mathrm{T}$ ( $\operatorname{Tr} 1$ ) cells [87] has been described. While in non-responsive individuals, $\operatorname{Tr} 1$ cells is the most common cell subtypes, allergen-specific IL-4 secreting Th2 cells predominates in allergic patients. Immunotherapy with the culprit venom comprising the allergens responsible for sensitization has proven to induce tolerance in 75-98\% treated patients [104].

A reliable diagnosis of HVA based on the detection of IgE-mediated reaction against the culprit venom is a critical prerequisite for initiation of venom immunotherapy [43]. Misidentification of venom responsible for sensitization leads to treatment with irrelevant venoms thus causing 
de novo non-specific sensitization and increase the risk for occurrence of undesired side effects during SIT. Thus, continuous efforts have been made to improve the available systems used for specific diagnosis of HVA. Diagnoses using crude venoms or native allergens are hindered by the potential incidence of IgE-mediated cross-reactivity mainly related to the presence of the CCDs in the structure of some allergenic proteins [36]. As mentioned below, the use recombinant allergens produced after identification and characterization of their native counterparts in venomic analyses have helped to cope with these pitfalls, thus enabling the specific identification of culprit venom [3]. The use of recombinant allergens lacking CCDs in CRD has resulted in a significant decrease on the incidence of cross-reactivity, with is responsible for $70-80 \%$ of misidentification of double sensitization informed during HVA diagnosis $[105,106]$. By preventing misdiagnoses these CCDs-depleted recombinant allergens avoid the inclusion of irrelevant venoms in SIT.

Venom immunotherapy is the only disease-modifying treatment for HVA and induces long-term tolerance in allergic patients [37]. As noted, SIT with insect venoms is highly effective in inducing tolerance in allergic patients [104]. However, the use of crude venom in immunotherapy have also been related to the occurrence of undesired side effects caused by non-allergenic, toxic compounds comprised in the extract [37]. The use of recombinant allergens could also improve the safety profile of SIT by preventing the inclusion of these non-allergenic components present in whole venom. Furthermore, venomic analyses have allowed identification of hypoallergenic variants of venom allergens [107]. Recombinant production of hypoallergenic proteins lacking IgE-epitopes but maintaining structural determinant for T-cell recognition and induction of allergen-blocking antibodies have been suggested as a novel alternative for improvement of SIT [108].

As noted, $P$. paulista is involved in a large number of medically important stinging incidents with potential life-threatening outcomes in allergic patients $[18,19,35]$. However, as for the others Hymenoptera species in Latin America, P. paulista-related sting accidents and venom allergy are neglected human health problems. The lack of reliable surveillance studies is partially due to the lack of commercial systems of diagnosis designed using allergens from endemic species [12,109]. To date, clinical interventions related to HVA in Brazil are mainly based on the use of crude venom extracts or commercialized allergens obtained from species of temperate regions. As discussed above, the use of these allergenic materials on Brazilian patients often resulted in missidentification of culprit venom which lead to non-specific sensitization $[7,35]$, increased risk of side effects and limited induction of tolerance during SIT [43]. Thus, it is mandatory to continue exploring the venom of Brazilian and in general neotropical wasps using intra and inter-specific analyses. These studies may help to identified novel allergenic proteins that could be heterologously expressed and evaluated for improvement of specific diagnosis and SIT of HVA caused by endemic native species. Furthermore, the analyses of intra and inter-species variations in wasp venoms and the correlation with differences in clinical symptoms could be used to establish a reliable prediction of the most probable effects on the victim triggered by a particular insect venom $[27,65]$.

Considering all these facts, the major allergens from $P$. paulista venom identified in venomic analysis have been extensively characterized, cloned and expressed. In this section we describe previous and recent analysis performed with the allergens envisioning their uses in the development of component resolved diagnosis and SIT of allergy.

\subsection{Phospholipase A2 (PLA2)}

As mentioned, early attempts to explore the proteinaceous arsenal of $P$. paulista venom resulted in identification of a group of highly glycosylated PLA2s-named polybitoxin (PbTX)-I, II, III and IV. Unlike PLA2 from A. mellifera (Api m 1) and from other social wasps [110,111], the polybitoxins induce no significant allergic reactions in the victim [23]. The total amount of the four PbTX in the crude venom of $P$. paulista represents only $1.1 \%$, a low value compared with those observed in the venoms from A. mellifera (10-12\%) and Vespa basalis (6\%) [22]. Nonetheless, this group of toxins showed levels of hemolytic activity higher than those of Api $\mathrm{m} 1$ or phospholipase A2 from venom of Naja nigricolis and Naja naja atra snakes. Given these, the role of PbTXs during $P$. paulista envenoming process is to cause hemolysis, a common feature of venom PLA2s [112,113], rather than to induce allergenic reactions.

\subsection{Phospholipase A1 (Poly p 1)}

Phospholipase A1 has been identified as a major allergen of several wasp venoms from neotropical $[39,114,115]$ and template regions [116-118]. The native PLA1 from P. paulista venom (Fig. 6A) is a $\sim 34 \mathrm{kDa}$, non-glycosylated protein with $51-83 \%$ of homology with vespid PLA1s from Northern Hemisphere. The enzyme catalyze the specific hydrolysis of ester bonds of 1,2-diacyl-3-sn glycerophospholipids, at the position $s n-1$ which disrupts phospholipid packing in cell membrane leading to pore formation and cellular lysis [39]. The nPoly p 1 showed levels of hemolytic activity similar to those reported for cobra cardotoxin Naja naja atra and reacted with sera of patient's allergy to $P$. paulista venoms. Further analysis of nPoly p 1 showed that the allergen appears as a mixture of multiple molecular forms, some truncated, and with different levels of allergenicity [119].

Purification and sequencing of nPoly $\mathrm{p} 1$ enabled the subsequent cloning and expression of the allergen. The combined use of bioinformatic, proteomic and molecular biology tools resulted in characterization of nPoly $\mathrm{p} 1$ and further heterologous production in E. coli cells [35]. Furthermore, structural data derived from molecular characterization of nPoly p 1 contributed to optimize the strategy for production of the recombinant allergen. The expression of Poly $\mathrm{p} 1 \mathrm{in} E$. coli resulted in the production and purification of an immunological active

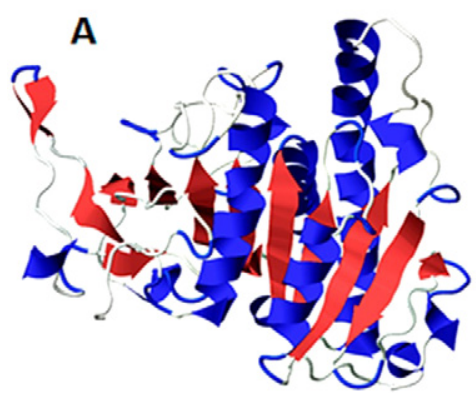

Poly $\mathrm{p} 1$

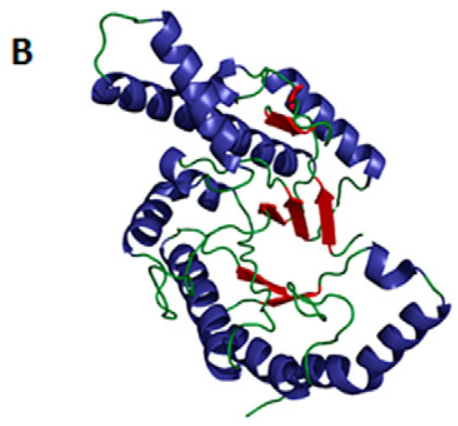

Poly p 2

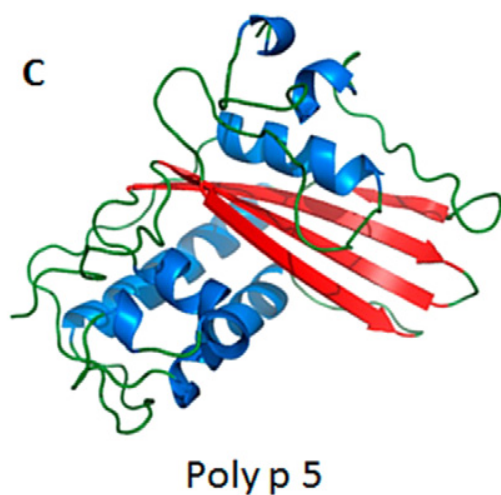

Fig. 6. Three dimensional molecular model of native phospholipase A1 (A), hyaluronidase (B) and antigen-5 (C), the major allergens from P. paulista wasp venom. 
recombinant allergen (rPoly p 1 ) that was immunodetected by sera of allergic patients at a similar extend than $P$. paulista crude venom extract and nPoly p 1 [35]. Furthermore, sera from rPoly p 1-sensitized mice specifically recognized nPoly $\mathrm{p} 1$ and showed no reaction with $A$. mellifera crude venom or commercial form of the major HBV allergens Api m 1, Api m 2 and melittin (Api m 4) [120]. Currently, rPoly p 1 has been evaluated to elucidate the incidence of cross-reactivity with venoms of wasp from neotropical and temperate climate zones. Overall, these findings suggest that rPoly $\mathrm{p} 1$ is a good candidate for the development of P. paulista CRD and molecular-defined IT.

\subsection{Hyaluronidase (Poly p 2)}

Proteomics analysis of $P$. paulista venom also enabled the isolation, sequencing and further molecular cloning of the native Poly $\mathrm{p} 2$ (nPoly p 2), the first hyaluronidase from neotropical wasp ever characterized [40]. Like other hyaluronidases from venomous animals, nPoly $\mathrm{p}$ 2 hydrolyze hyaluronic acid, a high molecular weight glycosaminoglycan which is one of the major components of the extracellular matrix of vertebrates [41]. Thus, the enzyme acts as a diffusion factor by facilitating the penetration of the others venom components in tissues and blood stream of the victim and finally enhancing the harmful effects of the toxins [93].

The nPoly p 2 variant described by Pinto et al., (2012) [40] is a glycosylated protein of 288 amino acid residues long with molecular mass of $44,340 \mathrm{Da}$. In contrast, nPoly p 2 purified, sequenced and modeled by Justo-Jacomini et al., (2013) [41] (Fig. 6B), is a 10 residues longer protein that showed $74.8 \%$ of identity with the nPoly p 2 previously described. As authors mentioned, the differences informed in these studies are rather due to the presence of several nPoly p 2 isoforms in P. paulista venom, previously described by dos Santos et al., (2011) [119], than to the variability of sites from wasps' collection or to modification in the experimental methods used.

As in the case of nPoly p 1, venomic analysis contributed to obtain a recombinant form of Poly p 2 (rPoly p 2 ) in E. coli [12]. rPoly p 2 was expressed in inclusion bodies, solubilized and purified to homogeneity using $\mathrm{Ni}^{2+}$ affinity chromatography (Ni-NTA-Agarose) under denaturing conditions. IgE-mediated immunodetection of the produced rPoly p 2 was confirmed by western blotting using sera from allergic patients. Interestingly, the immune sera from $P$. paulista-allergic patients recognized rPoly $\mathrm{p} 2$ at higher intensity than nPoly $\mathrm{p} 2$ showing that Poly $\mathrm{p}$ 2 lineal-IgE epitopes elicited a potent immune response in sensitized victims. This finding is particularly relevant in the case of Poly p 2, as the recombinant form expressed in E. coli lacked the CCDs thus decreasing the potential negative impact of cross-reactive occurrence during diagnosis based on the crude venom extract or native form of the allergen.

\subsection{Antigen 5 (Poly p 5)}

Antigen 5 is a ubiquitous protein of $\sim 23 \mathrm{kDa}$ that belongs to the CAP superfamily of secreted proteins which are involved in diverse biological process (reproduction, cancer, immune defense, allergic reactions) [121]. In social Hymenoptera, antigen 5 was initially reported as a venom component of ants and wasps from Northern Hemisphere [122]. Although it is one of the most abundant proteinaceous component of wasp venoms [3,123], no physiological role has been described for the protein [43]. Unlike the two others major allergens, the first clue about the presence of antigen 5 in P. paulista was obtained from the systemic analysis performed by dos Santos et al., (2010) [23] after 2D-E separation of the venom proteome followed by mass spectrometry analysis. In this study, six isoforms of nPoly p 5 were identified and the most abundant, which corresponds to the intact form of this protein, was recognized by a pool of sera from $P$. paulista-allergic patients. The authors suggested that the six isoforms of the allergens are originated from a controlled proteolytic processing of the intact protein or by gene splicing. The production of different isoforms could represent a strategy to avoid the immune response of the victim against a specific variant of the allergen thus enabling immune system evasion during envenoming process.

Given these results, further efforts were made to sequence and characterize Poly p 5. Using a gel based mass spectrometry strategy combined with traditional techniques from protein sequencing and posttranslational modifications (PTMs) analysis, a complete sequence and structural model of the allergen were obtained. A series of PTMs modifications such as hydroxylation, phosphorylation, and glycosylation were observed on the Poly $\mathrm{p} 5$ sequence. Alignment of nPoly $\mathrm{p} 5$ primary sequence revealed a 59.3-93.7\% identity with antigen 5 of other wasp venoms. Meanwhile, the 3D model showed the presence of three $\alpha$-helices, one $3_{10}$ helix, and four $\beta$-sheets (Fig. 6C) [42]. The high levels of identity with antigen 5 of others social Hymenoptera partially explain the broad cross-reactivity reported for these allergens during allergy diagnosis [118,124].

The allergenicity of antigen 5 from Hymenoptera venoms and the lack of knowledge about enzymatic or other physiological activities have encouraged the efforts for heterologous production of this allergen. In addition to be helpful in allergy diagnosis and immunotherapy, the recombinant forms of the antigen 5 could be used in different assays for structural and functional characterization. To date, antigen 5 from venom of social Hymenoptera has been expressed in bacteria [125, 126], yeast [107] and insect cells [118,127]. Some of the heterologous forms of the allergen have proved to significantly improve CRD of Hymenoptera venom allergy $[105,128]$.

Based on these findings and the data obtained from proteomic characterization of nPoly p 5, two studies are currently conducted to express the allergen in prokaryotic and yeast cells. Interestingly, a novel alternative for the development of molecular-defined IT has been suggested recently after the description of several B-cell linear epitopes of nPoly p 5 [44]. By combining SPOT-synthesis technique and structural modeling of Poly p 5, the authors identified nine linear B-cell epitopes immunoreactive to human IgG, one of which, peptide 7 (WAKTKE) also reacts with human IgE. It was suggested that peptide 7 is settled at a loop on the protein surface representing the major B-cell binding epitope of the $P$. paulista venom antigen 5 . The use of synthetic peptides based on the described epitopes could provide a safe and effective strategy to induce tolerance in the allergic patients without the occurrence of adverse effects [129].

The combined use of rPoly p 1, 2 and 5 in panels of recombinant allergens could significantly improve the specific diagnosis of $P$. paulista venom allergy in sensitized patients. However, further analyses are required for immunological characterization of the produced heterologous forms. Moreover, other allergenic proteins that must be underrepresented in the crude venom extract but are still recognized by specific IgE in allergic patients [130], should be characterized, heterologously expressed and tested. It has been well stablished that the use of a reduced number of recombinant allergens in CRD is associated with a decrease in sensitivity and a consequently increase of false negative results [131]. As mentioned, in a systemic profiling of the wasp venom, Santos et al., (2010) [23] found 16 single spots that reacted with sera of $P$. paulista venom-allergic patients which could be evaluated and included in CRD and venom immunotherapy.

\section{Potential biotechnological applications}

Animal venoms are unique cocktails of bioactive toxins that target a wide variety of physiological processes. Most of these toxins specifically interact with vital enzymes, ion channels and cellular receptors [54]. Due to these, animal venoms have been explored as a source of potential therapeutic agents. P. paulista venom comprised a rich mixture of peptides and proteins that could be evaluated not only for the rational design of antivenoms, but also as a source for the development of novel drugs. 
To date, mainly P. paulista venom peptides have been evaluate as candidates for the development of novel drugs. Meanwhile, major allergenic proteins have been extensively characterized, produced as recombinant protein and are currently under evaluation envisioning their use in commercial system for CRD of $P$. paulista venom allergy. As mentioned, the bottom-up gel based proteomic approach used for the systemic analysis of the wasp venom resulted in the identification of a limited number of proteins (84/236 spots) [23] which potentially hampered the detection of novel toxins. In addition to expand our understanding of the envenoming process the use of a gel-free shotgun proteomic approach could potentially allow the discovery of proteins with novel pharmaceutical applications.

\subsection{Antimicrobial and antifungal activity}

Antimicrobial resistance (AMR) has progressively turned into a serious threat for modern medicine as recognized in a global report recently published by the World Health Organization [132]. Current situation has prompted the search for new antimicrobial compounds with alternative mechanisms of action that could be used solely or combined with traditional drugs to tackle bacterial, fungal, parasites and virus drugs resistance. Antimicrobial activity is a common feature of animal venoms and is related to a wide range of peptidic toxins such as mastoparans [32], cardiotoxins [133], cecropins [134], mellitin [135] and some enzymes [136]. Unlike conventional antibiotics, which interact with specific bacterial targets, some venom AMPs act by direct disruption of cell surface [136-138]. This microbicidal mechanism usually prevents the appearance of AMR-mediated by gene mutations and is less likely to induce resistance [139]. Due to this, animal venoms could be explored as potential sources of novel and non-easily susceptible to resistance antibiotics [140].

Several antimicrobial compounds with unique structure and pharmacological properties have been described in Hymenoptera venoms [86,141]. As mentioned, some P. paulista venom-peptides including the mastoparans Polybia-MPI, -II, -III and chemotactic peptide Polybia$\mathrm{CP}[52,60]$ has showed different levels of activity against Gram positive and/or negative bacteria. The analysis of the molecular mechanism of action is a mandatory prerequisite for the development of novel antibiotics using these compounds.

Unlike other venoms peptides, Polybia-MPI is a non-hemolytic toxin that showed significant and highly selective antimicrobial activity. The differential interaction of this venom toxin with bacterial and red blood cells was suggested to be related with the peptide structure and cell membrane composition [59]. Further analysis toward elucidation of Polybia-MP-I mechanism of action showed that the selectivity for bacterial cells is associated with the ratio of peptide and membrane lipids $(\mathrm{P} / \mathrm{L})$ concentrations needed to reach a point of starting a cooperative leakage process [142]. The permeabilization triggering $(\mathrm{P} / \mathrm{L})$-ratio for Polybia-MP-I varies between different cell types as a function of the membrane lipid bilayer composition and partially explain the peptide specificity. In vitro analyses showed that Polybia-MPI preferentially interacts with anionic over zwitterionic vesicles. This finding is consistent with the selective antimicrobial activity of the peptide since outer leaflet of bacterial membranes are known to present a high negative charge density [143] whereas mammalian membranes are mainly formed by zwitterionic lipids. Overall, these findings pointed to Polybia-MP-I as an interesting candidate for development of potentially highly selective and effective antibiotics.

The antimicrobial mechanism of action of Polybia-CP has been described recently using a set of both Gram $(+)$ and Gram $(-)$ bacteria [144]. The P. paulista-chemotactic peptide showed a significant antimicrobial and bactericidal activity against several pathogenic strains. Polybia-CP effects over E. coli cells could be visualized by electron microscopy after $30 \mathrm{~min}$ of exposure. The action was characterized by the appearance of disrupted membrane surface likely related to pore formation. The venom toxin causes permeabilization of bacterial outer and inner membrane as showed by the incorporation of a hydrophobic fluorescent probe and a DNA-intercalating fluorescent dye, respectively. The authors also looked for peptide-bacterial DNA interaction in an attempt to determine alternative molecular targets. Polybia-CP showed no interaction with DNA reinforcing the suggestion that bacterial membrane is the unique target for the chemotactic peptide. Further analyses are required to evaluate the selectivity of Polybia-CP. However, the fact that its mode of action involves only physical interaction with cellular membranes and no enzymatic activities reduces the possibilities of drug-resistance emerging, a characteristic that is highly desired in novel antimicrobial compounds.

Polybia-MP-I [145] and Polybia-CP [146] also inhibits fungal cells growth. Both venom peptides have shown a significantly antifungal and fungicidal activity against different species of Candida. In addition to cause membrane disruption, Polybia-MP-I interacted with components of the fungal cell wall thus suggesting a concomitant mechanism of action for antifungal activity. Interestingly, further functional analysis showed that Polybia-MPI impaired biofilm formation which a typical defense strategy of pathogenic microorganisms against host immune system and drugs. The antifungal activity of Polybia-CP is also mediated by a membrane-active mode of action. Interestingly, bioassays also showed that the chemotactic peptide induce a remarkable increase of cellular reactive oxygen species (ROS) which damage proteins, lipids and DNA of fungal cells. Thus, both $P$. paulista venom peptides appear as good candidates for developments of antifungal drugs or as lead structure for the rational design of more active analogues.

\subsection{Antitumor activity}

To date, cancer remains the second most common cause of death among human population and it is expected to surpass heart disease as the leading cause during the next years [147]. Chemotherapy has been broadly used as an effective approach to prolong life and/or relieve symptoms in patients. However, as in the case of pathogenic microorganisms, the tumor cells-multidrug resistance is a major problem causing failure of anti-cancer therapeutic pharmacological interventions [148]. Moreover, current drugs have harmful actions over non-target cells, causing significant undesired-side effects. Thus, the search for novel, tumor-cell selective compounds with low probability of resistance emerging has turned into a priority for anti-cancer researches.

Antimicrobial peptides have shown to exert cytotoxic activity against diverse cancer cell lines [141]. So far, the antitumor effects of P. paulista-venom toxins have been tested for the mastoparan PolybiaMPI. This peptide showed a highly selective cytotoxic and antiproliferative activity against prostate and bladder cancer cells [45]. As in the case of bacteria, Polybia-MPI antitumor activity appears to be related to the presence of $\alpha$-helix conformation in the secondary structure of the venom peptide that mediates pore formation in membrane of tumor cells. Interestingly, proliferation of the non-tumorigenic murine fibroblast cell line NIH3T3 was almost unaffected by Polybia-MPI.

In a subsequent analysis conducted using sensitive and multi-drug resistant leukemic cell lines, Polybia-MPI showed a highly selective antiproliferative effect [138]. Cytotoxicity levels of Polybia-MPI were similar in both types of leukemic cells while no damage was detected in NIH3T3 cells. Further analysis of the mechanism of action showed that the peptide activity is mediated by the highest content of phosphatidylserine (PS) in the cell membrane of leukemic cells. In normal physiological conditions PS is located in the membrane's inner leaflet while tumorigenic cells experiment a significant increase of PS in the outer leaflet. As Polybia-MPI preferentially interacts with PS, the authors proposed that the differential distribution of PS in normal and tumorigenic cells promotes selective anti-cancer activity of the P. paulista venom mastoparan.

Recently, Leite et al., (2015) [46] extended these results and showed that PS increase the Polybia-MPI binding to cell surface by a factor of 7-8. Moreover, this work found that not only PS but also phosphatidylethanolamine (PE) plays a critical role in the anti- 
tumorigenic action of the peptide. Higher levels of PE content in cell membranes correlated to an increase in pore size and permeabilization. Since an increase in PE content is also observed in cancer cells, authors suggested that PS/PE synergistically enhances the activity of Polybia-MPI in cancerous cells.

As mentioned in this review, proteomic analysis of animal venoms combined with characterization of individual components could lead to rational design of novel biotechnological products. Using the structural and functional findings described here, Zhang et al., (2010) [149] further synthesized and characterized the in vivo antitumor activity of a Polybia-MPI analogue (MPI-1). In addition of a significant increase in resistance to enzymatic degradation, the modified peptide exhibited an enhanced lytic effect along with a remarkably lower mortality rates in mice when compared with Polybia-MPI. In summary, the results pointed to Polybia-MPI-1 as an improved variant of Polybia-MPI to be considered in the rational development of peptide-based anti-cancer drugs.

\section{Concluding remarks}

Venoms from Hymenoptera species have evolved as a defensive/ predatory chemical weapon to be used against colony predators and to capture prey. Therefore, they represent unique cocktails of bioactive molecules with a wide range of biological functions that work synergistically during the envenoming process. Venom profiling and molecular characterization based on the combined use of different -omic- approaches is a mandatory prerequisite for the development of novel antivenoms and for the rational design of strategies to cope with HVA. For almost two decades, the venom of the neotropical social wasp P. paulista has been explored in order to elucidate the toxins-arsenal displayed in the victims after the insect sting. Like in the case of other venomous animals, the strategies used for biochemical and functional characterization of $P$. paulista venom have moved from traditional proteomic techniques, focusing in identification of a limited number of venom compounds, to systemic venomic approaches. P. paulista venom profiling resulted in the identification and molecular characterization of dozens of toxins, thus enhancing our understanding of the envenoming process. Overall, these findings enabled the development of allergy-CRD based in recombinant allergens and the search of novel $P$. paulista-venom derived biopharmaceuticals. Furthermore, venomic analyses of $P$. paulista represent a model for toxinology studies of other Hymenoptera taxon that could result in the identification of novel pharmacologically relevant molecules and the improvement of systems used for diagnosis of HVA caused by other clinically relevant insects.

\section{Acknowledgments}

We acknowledge the financial support from FAPESP (São Paulo Research Foundation), (Grant numbers: 2006/54799-6, 2014/13936-7 and 2011/51684-1) and from FUNDUNESP-UNESP (Grant number: 01197/10-DFP). M.S.P. is a researcher from the National Research Council of Brazil-CNPq. The authors thank to CAPES-DS (Coordenação de Aperfeiçoamento de Pessoal de Nível Superior), Postgraduate Program of Biological Sciences (Cellular and Molecular Biology) at UNESP, Rio Claro and FAPESP (Grant Number 2013/26451-9) for providing a Doctoral and a Post-Doctoral scholarship to A.P.R. and J.R.A.d S.P., respectively. The authors also want to thank Felina Lenkeit for providing useful comments regarding the first draft of the manuscript and for the English proofreading.

\section{References}

[1] M.B. Bilò, Anaphylaxis caused by Hymenoptera stings: from epidemiology to treatment, Allergy Eur. J. Allergy Clin. Immunol. 66 (2011) 35-37, http://dx.doi.org/10. 1111/j.1398-9995.2011.02630.x.
[2] M.S. Palma, Hymenoptera venom peptides, in: Abba Kastin (Ed.), Handb. Biol. Act. Pept, second ed.Academic press/Elsevier, San Diego 2013, pp. 416-422.

[3] E. Spillner, S. Blank, T. Jakob, Hymenoptera allergens: from venom to "venome,", Front. Immunol. 5 (2014) 1-7, http://dx.doi.org/10.3389/fimmu. 2014.00077.

[4] H.A. Arcuri, P.C. Gomes, B.M. de Souza, N.B. Dias, P. Brigatte, R.G. Stabeli, M.S Palma, Paulistine-the functional duality of awasp venom peptide toxin, Toxins (Basel) 8 (2016)http://dx.doi.org/10.3390/toxins8030061.

[5] K.T. Fitzgerald, A.A. Flood, Hymenoptera stings, Clin. Tech. Small Anim. Pract. 21 (2006) 194-204, http://dx.doi.org/10.1053/j.ctsap.2006.10.002.

[6] J.J. Calvete, L. Sanz, D. Pla, B. Lomonte, J.M. Gutiérrez, Omics meets biology: application to the design and preclinical assessment of antivenoms, Toxins (Basel). 6 (2014) 3388-3405, http://dx.doi.org/10.3390/toxins6123388.

[7] A. Perez-Riverol, D.L. Justo-Jacomini, R. de Lima Zollner, M.R. Brochetto-Braga, Facing hymenoptera venom allergy: from natural to recombinant allergens, Toxins (Basel). 7 (2015) 2551-2570, http://dx.doi.org/10.3390/toxins7072551.

[8] J.J. Calvete, B. Lomonte, A bright future for integrative venomics, Toxicon 107 (2015) 159-162, http://dx.doi.org/10.1016/j.toxicon.2015.10.024.

[9] D.C. de Graaf, M. Aerts, E. Danneels, B. Devreese, Bee, wasp and ant venomics pave the way for a component-resolved diagnosis of sting allergy, J. Proteome 72 (2009) 145-154, http://dx.doi.org/10.1016/j.jprot.2009.01.017.

[10] R.J. Boyle, M. Elremeli, J. Hockenhull, M.G. Cherry, M.K. Bulsara, M. Daniels, J.N.G. Oude Elberink, Venom immunotherapy for preventing allergic reactions to insect stings, Cochrane Database Syst. Rev. 10 (2012), CD008838. http://dx.doi.org/10. 1002/14651858.CD008838.pub2.

[11] G.D.A. Locher, O.C. Togni, O.T. Silveira, E. Giannotti, The social wasp fauna of a Riparian forest in southeastern Brazil (Hymenoptera, Vespidae), Sociobiology 61 (2014) 225-233, http://dx.doi.org/10.13102/sociobiology.v61i2.225-233.

[12] D.L. Justo Jacomini, S.M. Gomes Moreira, F.D. Campos Pereira, R.D.L. Zollner, M.R Brochetto Braga, Reactivity of IgE to the allergen hyaluronidase from Polybia paulista (Hymenoptera, Vespidae) venom, Toxicon 82 (2014) 104-111, http://dx. doi.org/10.1016/j.toxicon.2014.02.016.

[13] WHO, Rabies and envenomings: a neglected public health issue: report of a Consultative Meeting, Who, 2007 32, http://dx.doi.org/10.1613/jair.301.

[14] Wanderley de Souza, Doenças Negligenciadas, Academia Brasileira de Ciências, Rio de Janeiro, 2010http://dx.doi.org/10.1590/0102-311X00111614.

[15] L. Antonicelli, M.B. Bilò, F. Bonifazi, Epidemiology of Hymenoptera allergy, Curr. Opin. Allergy Clin. Immunol. 2 (2002) 341-346.

[16] B.M. Bilò, F. Bonifazi, Epidemiology of insect-venom anaphylaxis, Curr. Opin. Allergy Clin. Immunol. 8 (2008) 330-337, http://dx.doi.org/10.1097/ACI. Ob013e32830638c5.

[17] S.H.G. Esher, A.P.B.M. Castro, J. Croce, M.S. Palma, O. Malaspina, M. de F.M. Palma J.E. Kalil, F.F.M. Castro, Estudo dos métodos laboratoriais utilizados no diagnóstico de alergia a Hymenoptera: análise crítica, Rev. Bras. Alerg. Imunopatol. 24 (2001) 46-53.

[18] M. Guimarães, Death swarm, Pesqui. FAPESP. (2009) 50-53.

[19] Serviço de Vigilância Sanitária (SVS), Animais Peçonhentos. Situação Epidemiológica: Dados. Casos de Acidentes por Abelhas. Brasil, Grandes Regiões e Unidades Federadas de 2000 a 2015, http://portalsaude.saude.gov.br/index. php/o-ministerio/principal/secretarias/svs/animais-peconhentos-abelha 2016 accesed January 26th/2017.

[20] K.M. Pickett, J.M. Carpenter, Simultaneous analysis and the origin of eusociality in the Vespidae (Insecta: Hymenoptera), Arthropod Syst. Phylogeny. 68 (2010) 3-33.

[21] R. De Barros Alvarenga, M.M. De Castro, H.H. Santos-Prezoto, F. Prezoto, Nesting of social wasps (Hymenoptera, Vespidae) in urban gardens in southeastern Brazil, Sociobiology 55 (2010) 445-452.

[22] M.R. De Oliveira, M.S. Palma, Polybitoxins: a group of phospholipases A2 from the venom of the neotropical social wasp paulistinha (Polybia paulista), Toxicon 36 (1998) 189-199, http://dx.doi.org/10.1016/S0041-0101(97)00053-6.

[23] L.D. Dos Santos, K.S. Santos, J.R.A. Pinto, N.B. Dias, B.M. De Souza, M.F. Dos Santos, J Perales, G.B. Domont, F.M. Castro, J.E. Kalil, M.S. Palma, Profiling the proteome of the venom from the social wasp Polybia paulista: a clue to understand the envenoming mechanism, J. Proteome Res. 9 (2010) 3867-3877, http://dx.doi.org/ $10.1021 /$ pr1000829.

[24] N.B. Dias, B.M. De Souza, P.C. Gomes, P. Brigatte, M.S. Palma, Peptidome profiling of venom from the social wasp Polybia paulista, Toxicon 107 (2015) 290-303, http:// dx.doi.org/10.1016/j.toxicon.2015.08.013.

[25] J.J. Calvete, Next-generation snake venomics: protein-locus resolution through venom proteome decomplexation, Expert Rev. Proteomics. 11 (2014) 315-329, http://dx.doi.org/10.1586/14789450.2014.900447.

[26] A.K. Tashima, A. Zelanis, E.S. Kitano, D. Ianzer, R.L. Melo, V. Rioli, S.S. Sant'anna, A.C.G. Schenberg, A.C.M. Camargo, S.M.T. Serrano, Peptidomics of three Bothrops snake venoms: insights into the molecular diversification of proteomes and peptidomes, Mol. Cell. Proteomics 11 (2012) 1245-1262, http://dx.doi.org/10. 1074/mcp.M112.019331.

[27] B. Lomonte, J. Fernández, L. Sanz, Y. Angulo, M. Sasa, J.M. Gutiérrez, J.J. Calvete, Venomous snakes of Costa Rica: biological and medical implications of their venom proteomic profiles analyzed through the strategy of snake venomics, J. Proteome 105 (2014) 323-339, http://dx.doi.org/10.1016/j.jprot.2014.02.020.

[28] A. Palagi, J.M.S. Koh, M. Leblanc, D. Wilson, S. Dutertre, G.F. King, G.M. Nicholson, P. Escoubas, Unravelling the complex venom landscapes of lethal Australian funnelweb spiders (Hexathelidae: Atracinae) using LC-MALDI-TOF mass spectrometry, J. Proteome 80 (2013) 292-310, http://dx.doi.org/10.1016/j.jprot.2013.01.002.

[29] T.F. Abreu, B.N. Sumitomo, M.Y. Nishiyama, U.C. de Oliveira, G.H.M.F. Souza, E.S Kitano, A. Zelanis, S.M.T. Serrano, I.J. de Azevedo, P.I. da Silva, A.K. Tashima, Peptidomics of Acanthoscurria gomesiana spider venom reveals new toxins with 
potential antimicrobial activity, J. Proteome (2016)http://dx.doi.org/10.1016/j. jprot.2016.07.012

[30] K.A. Newton, M.R. Clench, R. Deshmukh, K. Jeyaseelan, P.N. Strong, Mass fingerprinting of toxic fractions from the venom of the Indian red scorpion, Mesobuthus tamulus: biotope-specific variation in the expression of venom peptides, Rapid Commun. Mass Spectrom. 21 (2007) 3467-3476.

[31] A. Verdes, P. Anand, J. Gorson, S. Jannetti, P. Kelly, A. Leffler, D. Simpson, G. Ramrattan, M. Holford, From mollusks to medicine: a venomics approach for the discovery and characterization of therapeutics from terebridae peptide toxins, Toxins (Basel) 8 (2016)http://dx.doi.org/10.3390/toxins8040117.

[32] K. Konno, K. Kazuma, K.-I. Nihei, Peptide toxins in solitary wasp venoms, Toxins (Basel) 8 (2016) 114, http://dx.doi.org/10.3390/toxins8040114.

[33] M. Van Vaerenbergh, G. Debyser, G. Smagghe, B. Devreese, D.C. De Graaf, Unraveling the venom proteome of the bumblebee (Bombus terrestris) by integrating a combinatorial peptide ligand library approach with FT-ICR MS, Toxicon 102 (2015) 81-88, http://dx.doi.org/10.1016/j.toxicon.2013.10.002.

[34] N.B. Dias, B.M. De Souza, P.C. Gomes, M.S. Palma, Peptide diversity in the venom of the social wasp Polybia paulista (Hymenoptera): a comparison of the intra- and inter-colony compositions, Peptides 51 (2014) 122-130, http://dx.doi.org/10. 1016/j.peptides.2013.10.029.

[35] A. Perez-Riverol, F.D. Campos Pereira, A. Musacchio Lasa, L.G. Romani Fernandes, J.R.A. dos Santos-Pinto, D.L. Justo-Jacomini, G. Oliveira de Azevedo, M.L. Bazon, M.S. Palma, R. de L. Zollner, M.R. Brochetto-Braga, Molecular cloning, expression and IgE-immunoreactivity of phospholipase A1, a major allergen from Polybia paulista (Hymenoptera: Vespidae) venom, Toxicon 124 (2016) 44-52, http://dx. doi.org/10.1016/j.toxicon.2016.11.006.

[36] M. Mertens, S. Amler, B.M. Moerschbacher, R. Brehler, Cross-reactive carbohydrate determinants strongly affect the results of the basophil activation test in Hymenoptera-venom allergy, Clin. Exp. Allergy 40 (2010) 1333-1345, http://dx.doi. org/10.1111/j.1365-2222.2010.03535.x

[37] F. Bonifazi, M. Jutel, B.M. Bilo, J. Birnbaum, U. Muller, Prevention and treatment of Hymenoptera venom allergy: guidelines for clinical practice, Allergy 60 (2005) 1459-1470, http://dx.doi.org/10.1111/j.1398-9995.2005.00960.x.

[38] C. Incorvaia, F. Frati, I. Dell'Albani, A. Robino, E. Cattaneo, M. Mauro, M. David, R. Qualizza, E. Pastorello, Safety of Hymenoptera venom immunotherapy: a systematic review, Expert. Opin. Pharmacother. 12 (2011) 2527-2532, http://dx.doi.org/ 10.1517/14656566.2011.616494 ET - 2011/09/03.

[39] L.D. Santos, K.S. Santos, B.M. de Souza, H.A. Arcuri, E. Cunha-Neto, F.M. Castro, J.E. Kalil, M.S. Palma, Purification, sequencing and structural characterization of the phospholipase A1 from the venom of the social wasp Polybia paulista (Hymenoptera, Vespidae), Toxicon 50 (2007) 923-937, http://dx.doi.org/10.1016/j.toxicon. 2007.06.027.

[40] J.R.A.D.S. Pinto, L.D. Dos Santos, H.A. Arcuri, N.B. Dias, M.S. Palma, Proteomic characterization of the hyaluronidase (E.C. 3.2.1.35) from the venom of the social wasp Polybia paulista, Protein Pept. Lett. 19 (2012) 625-635, http://dx.doi.org/10.2174/ 092986612800494039.

[41] D.L. Justo Jacomini, F.D. Campos Pereira, J.R. Aparecido dos Santos Pinto, L.D. dos Santos, A.J. da Silva Neto, D.T. Giratto, M.S. Palma, R. de Lima Zollner, M.R. Brochetto Braga, Hyaluronidase from the venom of the social wasp Polybia paulista (Hymenoptera, Vespidae): cloning, structural modeling, purification, and immunological analysis, Toxicon 64 (2013) 70-80, http://dx.doi.org/10.1016/j.toxicon. 2012.12.019.

[42] J.R.A. Dos Santos-Pinto, L.D. Dos Santos, H. Andrade Arcuri, F.M. Castro, J.E. Kalil, M.S. Palma, Using proteomic strategies for sequencing and post-translational modifications assignment of antigen-5, a major allergen from the venom of the social wasp Polybia paulista, J. Proteome Res. 13 (2014) 855-865, http://dx.doi.org/10 1021/pr4008927.

[43] M. Ollert, S. Blank, Anaphylaxis to insect venom allergens: role of molecular diagnostics, Curr. Allergy Asthma Rep. 15 (2015)http://dx.doi.org/10.1007/s11882 015-0527-z.

[44] J.R. Aparecido Dos Santos-Pinto, L. Delazari Dos Santos, H.A. Arcuri, A. Ribeiro Da Silva Menegasso, P.N. Pêgo, K.S. Santos, F.M. Castro, J.E. Kalil, S.G. De-Simone, M.S. Palma, B-cell linear epitopes mapping of antigen-5 allergen from Polybia paulista wasp venom, J. Allergy Clin. Immunol. 135 (2015) 264-267, http://dx doi.org/10.1016/j.jaci.2014.07.006.

[45] K. Wang, B. Zhang, W. Zhang, J. Yan, J. Li, R. Wang, Antitumor effects, cell selectivity and structure-activity relationship of a novel antimicrobial peptide polybia-MPI, Peptides 29 (2008) 963-968, http://dx.doi.org/10.1016/j. peptides.2008.01.015.

[46] N.B. Leite, A. Aufderhorst-Roberts, M.S. Palma, S.D. Connell, J.R. Neto, P.A. Beales, PE and PS lipids synergistically enhance membrane poration by a peptide with anticancer properties, Biophys. J. 109 (2015) 936-947, http://dx.doi.org/10.1016/j. bpj.2015.07.033.

[47] M. Van Vaerenbergh, G. Debyser, B. Devreese, D.C. de Graaf, Exploring the hidden honeybee (Apis mellifera) venom proteome by integrating a combinatorial peptide ligand library approach with FTMS, J. Proteome 99 (2014) 169-178, http://dx.doi. org/10.1016/j.jprot.2013.04.039.

[48] J. Matysiak, J. Hajduk, Ł. Pietrzak, C.E.H. Schmelzer, Z.J. Kokot, Shotgun proteome analysis of honeybee venom using targeted enrichment strategies, Toxicon 90 (2014) 255-264, http://dx.doi.org/10.1016/j.toxicon.2014.08.069.

[49] B.M. de Souza, M.R. Marques, D.M. Tomazela, M.N. Eberlin, M.A. Mendes, M.S Palma, Mass spectrometric characterization of two novel inflammatory peptides from the venom of the social wasp Polybia paulista, Rapid Commun. Mass Spectrom. 18 (2004) 1095-1102, http://dx.doi.org/10.1002/rcm.1452.

[50] A. Behrens, N. Maie, H. Knicker, I. Kögel-Knabner, MALDI-TOF mass spectrometry and PSD fragmentation as means for the analysis of condensed tannins in plant leaves and needles, Phytochemistry 62 (2003) 1159-1170, http://dx.doi.org/10. 1016/S0031-9422(02)00660-X.

[51] S.P. Ribeiro, M.A. Mendes, L.D. Dos Santos, B.M. De Souza, M.R. Marques, W.F. De Azevedo, M.S. Palma, Structural and functional characterization of N-terminally blocked peptides isolated from the venom of the social wasp Polybia paulista, Peptides 25 (2004) 2069-2078, http://dx.doi.org/10.1016/j.peptides.2004.08.019.

[52] B.M. Souza, M.A. Mendes, L.D. Santos, M.R. Marques, L.M.M. César, R.N.A. Almeida, F.C. Pagnocca, K. Konno, M.S. Palma, Structural and functional characterization of two novel peptide toxins isolated from the venom of the social wasp Polybia paulista, Peptides 26 (2005) 2157-2164, http://dx.doi.org/10.1016/j.peptides. 2005.04.026.

[53] D.M. Saidemberg, L.C. Da Silva-Filho, L.M.M.C. Tognoli, C.F. Tormena, M.S. Palma, Polybioside, a neuroactive compound from the venom of the social wasp Polybia paulista, J. Nat. Prod. 73 (2010) 527-531, http://dx.doi.org/10.1021/np900424t.

[54] J.J. Calvete, L. Sanz, Y. Angulo, B. Lomonte, J.M. Gutiérrez, Venoms, venomics, antivenomics, FEBS Lett. 583 (2009) 1736-1743, http://dx.doi.org/10.1016/j. febslet.2009.03.029.

[55] N. Peiren, F. Vanrobaeys, D.C. De Graaf, B. Devreese, J. Van Beeumen, F.J. Jacobs, The protein composition of honeybee venom reconsidered by a proteomic approach, Biochim. Biophys. Acta, Proteins Proteomics 1752 (2005) 1-5, http://dx.doi.org/ 10.1016/j.bbapap.2005.07.017.

[56] J. Matysiak, C.E.H. Schmelzer, R.H.H. Neubert, Z.J. Kokot, Characterization of honeybee venom by MALDI-TOF and nanoESI-QqTOF mass spectrometry, J. Pharm. Biomed. Anal. 54 (2011) 273-278, http://dx.doi.org/10.1016/j.jpba.2010.08.020.

[57] C.L. Mills, P.J. Beuning, M.J. Ondrechen, Biochemical functional predictions for protein structures of unknown or uncertain function, Comput. Struct. Biotechnol. J. 13 (2015) 182-191, http://dx.doi.org/10.1016/j.csbj.2015.02.003.

[58] N. Nadzirin, M. Firdaus-Raih, Proteins of unknown function in the protein data bank (PDB): an inventory of true uncharacterized proteins and computational tools for their analysis, Int. J. Mol. Sci. 13 (2012) 12761-12772, http://dx.doi.org/ 10.3390/ijms131012761.

[59] M.A. Mendes, B.M. De Souza, M.S. Palma, Structural and biological characterization of three novel mastoparan peptides from the venom of the neotropical social wasp Protopolybia exigua (Saussure), Toxicon 45 (2005) 101-106, http://dx.doi.org/10. 1016/j.toxicon.2004.09.015.

[60] B.M. de Souza, A.V.R. da Silva, V.M.F. Resende, H.A. Arcuri, M.P. dos Santos Cabrera, J. Ruggiero Neto, M.S. Palma, Characterization of two novel polyfunctional mastoparan peptides from the venom of the social wasp Polybia paulista, Peptides 30 (2009) 1387-1395, http://dx.doi.org/10.1016/j.peptides.2009.05.008.

[61] M.A. Abdel-Rahman, I.M. Abdel-Nabi, M.S. El-Naggar, O.A. Abbas, P.N. Strong, Intraspecific variation in the venom of the vermivorous cone snail Conus vexillum, Comp. Biochem. Physiol. - C Toxicol. Pharmacol. 154 (2011) 318-325, http://dx. doi.org/10.1016/j.cbpc.2011.06.019.

[62] M.B. Bilò, F. Bonifazi, The natural history and epidemiology of insect venom allergy: clinical implications, Clin. Exp. Allergy 39 (2009) 1467-1476, http://dx.doi.org/10. 1111/j.1365-2222.2009.03324.x.

[63] N.B. Baptista-Saidemberg, D.M. Saidemberg, M.S. Palma, Profiling the peptidome of the venom from the social wasp Agelaia pallipes pallipes, J. Proteome 74 (2011) 2123-2137, http://dx.doi.org/10.1016/j.jprot.2011.06.004.

[64] J.R.A. Dos Santos Pinto, E.G.P. Fox, D.M. Saidemberg, L.D. Santos, A.R. Da Silva Menegasso, E. Costa-Manso, E.A. MacHado, O.C. Bueno, M.S. Palma, Proteomic view of the venom from the fire ant Solenopsis invicta buren, J. Proteome Res. 11 (2012) 4643-4653, http://dx.doi.org/10.1021/pr300451g.

[65] B. Przybilla, F. Ruëff, Hymenoptera Venom Allergy, 2010, 2010 114-129, http://dx. doi.org/10.1111/j.1610-0387.2009.07125.x.

[66] F.G. Esteves, J.R.A. dos Santos-Pinto, D.M. Saidemberg, M.S. Palma, Using a proteometabolomic approach to investigate the role of Dufour's gland in pheromone biosynthesis in the social wasp Polybia paulista, J. Proteome 151 (2015) 122-130, http://dx.doi.org/10.1016/j.jprot.2016.01.009.

[67] A. Mitra, Function of the Dufour's gland in solitary and social Hymenoptera, J. Hymenopt. Res. 35 (2013) 33-58, http://dx.doi.org/10.3897/jhr.35.4783.

[68] H.F. Gomez, D.M. Greenfield, M.J. Miller, J.S. Warren, Direct correlation between diffusion of Loxosceles reclusa venom and extent of dermal inflammation, Acad. Emerg. Med. 8 (2001) 309-314.

[69] K.S. Girish, R. Shashidharamurthy, S. Nagaraju, T.V. Gowda, K. Kemparaju, Isolation and characterization of hyaluronidase a "spreading factor" from Indian cobra (Naja naja) venom, Biochimie 86 (2004) 193-202, http://dx.doi.org/10.1016/j.biochi. 2004.02.004.

[70] K.C.F. Bordon, G.A. Wiezel, F.G. Amorim, E.C. Arantes, Arthropod venom hyaluronidases: biochemical properties and potential applications in medicine and biotechnology, J. Venom. Anim. Toxins Incl. Trop. Dis. 21 (2015) 43, http://dx.doi.org/10. 1186/s40409-015-0042-7.

[71] P. Rungsa, P. Incamnoi, S. Sukprasert, N. Uawonggul, S. Klaynongsruang, J. Daduang, R. Patramanon, S. Roytrakul, S. Daduang, Cloning, structural modelling and characterization of VesT2s, a wasp venom hyaluronidase (HAase) from Vespa tropica, J. Venom. Anim. Toxins Incl. Trop. Dis. 22 (2016) 28, http://dx.doi. org/10.1186/s40409-016-0084-5.

[72] E. Habermann, Bee and wasp venoms, Science 177 (1972) 314-322, http://dx.doi. org/10.1126/science.177.4046.314

[73] V.P. Ferrer, T.L. de Mari, L.H. Gremski, D. Trevisan Silva, R.B. da Silveira, W. Gremski, O.M. Chaim, A. Senff-Ribeiro, H.B. Nader, S.S. Veiga, A novel hyaluronidase from brown spider (Loxosceles intermedia) venom (Dietrich's Hyaluronidase): from cloning to functional characterization, PLoS Negl. Trop. Dis. 7 (2013) 1-12, http://dx.doi.org/10.1371/journal.pntd.0002206.

[74] A.F. Wahby, E.S.M.E. Mahdy, H.A. EL-mezayen, W.H. Salama, A.M. Abdel-Aty, A.S. Fahmy, Egyptian horned viper Cerastes cerastes venom hyaluronidase: purification, 
partial characterization and evidence for its action as a spreading factor, Toxicon 60 (2012) 1380-1389, http://dx.doi.org/10.1016/j.toxicon.2012.08.016.

[75] K. Kemparaju, K.S. Girish, Snake venom hyaluronidase: a therapeutic target, Cell Biochem. Funct. 24 (2006) 7-12, http://dx.doi.org/10.1002/cbf.1261.

[76] R. Arce-Bejarano, B. Lomonte, J.M. Gutiérrez, Intravascular hemolysis induced by the venom of the eastern coral snake, Micrurus fulvius, in a mouse model: identification of directly hemolytic phospholipases A2, Toxicon 90 (2014) 26-35, http:// dx.doi.org/10.1016/j.toxicon.2014.07.010.

[77] D.-M. Chen, P.-T. Lee, K.-J. Chou, H.-C. Fang, H.-M. Chung, L.-K. Chang, Descending aortic thrombosis and cerebral infarction after massive wasp stings, Am. J. Med. 116 (2004) 567-569, http://dx.doi.org/10.1016/j.amjmed.2003.08.036.

[78] E. Jamasbi, S. Batinovic, R.A. Sharples, M.A. Sani, R.M. Robins-Browne, J.D. Wade, F. Separovic, M.A. Hossain, Melittin peptides exhibit different activity on different cells and model membranes, Amino Acids 46 (2014) 2759-2766, http://dx.doi. org/10.1007/s00726-014-1833-9.

[79] K.H. Slotta, J.A. Vick, Identification of the direct lytic factor from cobra venom as cardiotoxin, Toxicon 6 (1969) (167in5169-168in6173).

[80] K.C.F. Bordon, M.G. Perino, J.R. Giglio, E.C. Arantes, Isolation, enzymatic characterization and antiedematogenic activity of the first reported rattlesnake hyaluronidase from Crotalus durissus terrificus venom, Biochimie 94 (2012) 2740-2748, http://dx.doi.org/10.1016/j.biochi.2012.08.014.

[81] J.M. Gutiérrez, T. Escalante, A. Rucavado, C. Herrera, Hemorrhage caused by snake venom metalloproteinases: a journey of discovery and understanding, Toxins (Basel). 8 (2016)http://dx.doi.org/10.3390/toxins8040093.

[82] V. Stiprija, V. Boonpuknavig, Renal failure and myonecrosis following wasp sting, Lancet 1 (1972) 749-750.

[83] E. Camacho, E. Villalobos, L. Sanz, A. Pérez, T. Escalante, B. Lomonte, J.J. Calvete, J.M. Gutiérrez, A. Rucavado, Understanding structural and functional aspects of PIl snake venom metalloproteinases: characterization of BlatH1, a hemorrhagic dimeric enzyme from the venom of Bothriechis lateralis, Biochimie 101 (2014) 145-155, http://dx.doi.org/10.1016/j.biochi.2014.01.008.

[84] J.M. Gutiérrez, B. Lomonte, Phospholipases A2: unveiling the secrets of a functionally versatile group of snake venom toxins, Toxicon 62 (2013) 27-39, http://dx.doi. org/10.1016/j.toxicon.2012.09.006.

[85] M.H. Hou, C.Y. Chuang, T.P. Ko, N.J. Hu, C.C. Chou, Y.P. Shih, C.L. Ho, A.H.J. Wang, Crystal structure of vespid phospholipase A1 reveals insights into the mechanism for cause of membrane dysfunction, Insect Biochem. Mol. Biol. 68 (2016) 79-88, http://dx.doi.org/10.1016/j.ibmb.2015.11.002.

[86] A. Touchard, S.R. Aili, E.G.P. Fox, P. Escoubas, J. Orivel, G.M. Nicholson, A. Dejean, The biochemical toxin arsenal from ant venoms, Toxins (Basel). 8 (2016) 1-28, http://dx.doi.org/10.3390/toxins8010030.

[87] C.A. Akdis, M. Akdis, Mechanisms of allergen-specific immunotherapy and immune tolerance to allergens, World Allergy Organ. J. 8 (2015) 17, http://dx.doi. org/10.1186/s40413-015-0063-2.

[88] S.A. Kozlov, V.N. Lazarev, E.S. Kostryukova, O.V. Selezneva, E.A. Ospanova, D.G. Alexeev, V.M. Govorun, E.V. Grishin, Comprehensive analysis of the venom gland transcriptome of the spider Dolomedes fimbriatus, Sci. Data 1 (2014) 140023. http://dx.doi.org/10.1038/sdata.2014.23.

[89] N.G. de O. Júnior, G. da R. Fernandes, M.H. Cardoso, F.F. Costa, E. de S. Cândido, D.G. Neto, M.R. Mortari, E.F. Schwartz, O.L. Franco, S.A. de Alencar, Venom gland transcriptome analyses of two freshwater stingrays (Myliobatiformes: Potamotrygonidae) from Brazil, Sci. Rep. 6 (2016) 21935, http://dx.doi.org/10. 1038/srep21935.

[90] S. Laurino, G. Grossi, P. Pucci, A. Flagiello, S.A. Bufo, G. Bianco, R. Salvia, S.B. Vinson, H. Vogel, P. Falabella, Identification of major Toxoneuron nigriceps venom proteins using an integrated transcriptomic/proteomic approach, Insect Biochem. Mol. Biol. 76 (2016) 49-61, http://dx.doi.org/10.1016/j.ibmb.2016.07.001.

[91] W. Bouzid, C. Klopp, M. Verdenaud, F. Ducancel, A. Vétillard, Profiling the venom gland transcriptome of Tetramorium bicarinatum (Hymenoptera: Formicidae): the first transcriptome analysis of an ant species, Toxicon 70 (2013) 70-81, http://dx.doi.org/10.1016/j.toxicon.2013.03.010.

[92] Z. Liu, S. Chen, Y. Zhou, C. Xie, B. Zhu, H. Zhu, S. Liu, W. Wang, H. Chen, Y. Ji, Deciphering the venomic transcriptome of killer-wasp Vespa velutina, Sci. Rep. 5 (2015) 9454, http://dx.doi.org/10.1038/srep09454.

[93] S.H. Lee, J.H. Baek, K.A. Yoon, Differential properties of venom peptides and proteins in solitary vs. social hunting wasps, Toxins (Basel) 8 (2016) 1-29, http://dx. doi.org/10.3390/toxins8020032.

[94] M. Moreno, E. Giralt, Three valuable peptides from bee and wasp venoms for therapeutic and biotechnological use: melittin, apamin and mastoparan, Toxins (Basel). 7 (2015) 1126-1150, http://dx.doi.org/10.3390/toxins7041126.

[95] K. Dohtsu, K. Okumura, K. Hagiwara, M.S. Palma, T. Nakajima, Isolation and sequence analysis of peptides from the venom of Protonectarina sylveirae (Hymenoptera-Vespidae), Nat. Toxins 1 (1993) 271-276.

[96] J.L. Fox, Antimicrobial peptides stage a comeback, Nat. Biotechnol. 31 (2013) 379.

[97] T. Rocha, B.M. de Souza, M.S. Palma, M.A. da Cruz-Höfling, Myotoxic effects of mastoparan from Polybia paulista (Hymenoptera, Epiponini) wasp venom in mice skeletal muscle, Toxicon 50 (2007) 589-599, http://dx.doi.org/10.1016/j. toxicon.2007.05.003.

[98] T. Rocha, M.B. Leonardo, B.M. De Souza, M.S. Palma, M.A. Da Cruz-Höfling, Mastoparan effects in skeletal muscle damage: an ultrastructural view until now concealed, Microsc. Res. Tech. 71 (2008) 220-229, http://dx.doi.org/10.1002/ jemt.20542.

[99] T. Rocha, L.L. Soares de Barros, K. Fontana, B. Monson de Souza, M.S. Palma, M. Alice da Cruz-Höfling, Inflammation and apoptosis induced by mastoparan Polybia-MPII on skeletal muscle, Toxicon 55 (2010) 1213-1221, http://dx.doi.org/10.1016/j. toxicon.2009.12.005
[100] F. Fratini, G. Cilia, B. Turchi, A. Felicioli, Insects, arachnids and centipedes venom: a powerful weapon against bacteria. A literature review, Toxicon (2017).

[101] N.B. Baptista-Saidemberg, D.M. Saidemberg, B.M. de Souza, L.M.M. César-Tognoli, V.M.R. Ferreira, M.A. Mendes, M.P. dos Santos Cabrera, J.R. Neto, M.S. Palma, Protonectin (1-6): a novel chemotactic peptide from the venom of the social wasp Agelaia pallipes pallipes, Toxicon 56 (2010) 880-889, http://dx.doi.org/10. 1016/j.toxicon.2010.06.011.

[102] L. Li, K. Chen, Y. Xiang, T. Yoshimura, S. Su, J. Zhu, X.-W. Bian, J.M. Wang, New development in studies of formyl-peptide receptors: critical roles in host defense, J. Leukoc. Biol. 99 (2015) 1-11, http://dx.doi.org/10.1189/jlb.2RI0815354RR.

[103] E.Ç. Mingomataj, A.H. Bakiri, A. Ibranji, G.J. Sturm, Unusual reactions to hymenoptera stings: what should we keep in mind? Clin. Rev. Allergy Immunol. 47 (2014) 91-99, http://dx.doi.org/10.1007/s12016-014-8434-y.

[104] D. Golden, Insect sting anaphylaxis, Immunol. Allergy Clin. N. Am. 27 (2007) 261-272, http://dx.doi.org/10.1038/jid.2014.371

[105] U. Müller, P. Schmid-Grendelmeier, O. Hausmann, A. Helbling, IgE to recombinant allergens Api m 1, Ves v 1, and Ves v 5 distinguish double sensitization from crossreaction in venom allergy, Allergy Eur. J. Allergy Clin. Immunol. 67 (2012) 1069-1073, http://dx.doi.org/10.1111/j.1398-9995.2012.02847.x.

[106] H. Seismann, S. Blank, I. Braren, K. Greunke, L. Cifuentes, T. Grunwald, R. Bredehorst, M. Ollert, E. Spillner, Dissecting cross-reactivity in hymenoptera venom allergy by circumvention of ??-1,3-core fucosylation, Mol. Immunol. 47 (2010) 799-808, http://dx.doi.org/10.1016/j.molimm.2009.10.005.

[107] S.E. Vinzón, M.L. Pirpignani, C. Nowicki, M.B. De Jimènez Bonino, Molecular cloning and expression in Pichia pastoris of a hypoallergenic antigen 5, Protein Expr. Purif. 73 (2010) 23-30, http://dx.doi.org/10.1016/j.pep.2010.03.029.

[108] P.L. Bhalla, M.B. Singh, Engineered allergens for immunotherapy, Curr. Opin. Allergy Clin. Immunol. 4 (2004) 569-573, http://dx.doi.org/10.1097/00130832200412000-00016.

[109] M.R. Perez-Riverol, A. Musacchio-Lasa, A. Romani-Fernandes, L.G. Santos-Pinto, J.R.A. Oliveira de Azevedo, G. Bazon, M.L. Palma, M.S. Zollner, R.L. BrochettoBraga, Improved Recombinant Production and Immunological Characterization of Phospholipase A1 from Polybia paulista Venom, Manuscript, 2017.

[110] R. Hoffman, D. Ph, H. Shipman, S. Diego, Allergens in Bee Venom, 58, 1976.

111] D.R. Hoffman, Allergens in Hymenoptera venom XIII: isolation and purification of protein components from three species of vespid venoms, J. Allergy Clin. Immunol. 75 (1985) 599-605, http://dx.doi.org/10.1016/0091-6749(85)90036-3.

[112] S. Estrada-Gomez, L.J.V. Muñoz, P. Lanchero, C.S. Latorre, Partial characterization of venom from the Colombian spider Phoneutria boliviensis (Aranae: Ctenidae) Toxins (Basel). 7 (2015) 2872-2887, http://dx.doi.org/10.3390/toxins7082872.

[113] W.F.B. Pessoa, L.C.C. Silva, L. de Oliveira Dias, J.H.C. Delabie, H. Costa, C.C. Romano, Analysis of protein composition and bioactivity of Neoponera villosa venom (Hymenoptera: Formicidae), Int. J. Mol. Sci. 17 (2016)http://dx.doi.org/10.3390/ ijms 17040513.

[114] S.A. Lockwood, J. HaghiPour-Peasley, D.R. Hoffman, R.J. Deslippe, Identification, expression, and immuno-reactivity of Sol i 2 \& Sol i 4 venom proteins of queen red imported fire ants, Solenopsis invicta Buren (Hymenoptera: Formicidae), Toxicon 60 (2012) 752-759, http://dx.doi.org/10.1016/j.toxicon.2012.05.011.

[115] S. Sukprasert, P. Rungsa, N. Uawonggul, P. Incamnoi, S. Thammasirirak, J. Daduang, S. Daduang, Purification and structural characterisation of phospholipase A1 (Vespapase, Ves a 1) from Thai banded tiger wasp (Vespa affinis) venom, Toxicon 61 (2013) 151-164, http://dx.doi.org/10.1016/j.toxicon.2012.10.024.

[116] T.P. King, A.C. Alagon, J. Kuan, A.K. Sobotka, L.M. Lichtenstein, Immunochemical studies of yellowjacket venom proteins, Mol. Immunol. 20 (1983) 297-308 http://dx.doi.org/10.1016/0161-5890(83)90069-X.

[117] T.P. King, G. Lu, M. Gonzalez, N. Oian, L. Soldatova, Yellow jacket venom allergens, hyaluronidase and phospholipase: sequence similarity and antigenic cross-reactivity with their hornet and wasp homologs and possible implications for clinical allergy, J. Allergy Clin. Immunol. 98 (1996) 588-600, http://dx.doi.org/10.1016/ S0091-6749(96)70093-3.

[118] P. Korošec, R. Valenta, I. Mittermann, N. Čelesnik, M. Šilar, M. Zidarn, M. Košnik High sensitivity of CAP-FEIA rVes v 5 and rVes $v 1$ for diagnosis of Vespula venom allergy, J. Allergy Clin. Immunol. 129 (2012) 1406-1408, http://dx.doi. org/10.1016/j.jaci.2011.12.975.

[119] L.D. dos Santos, A.R. da Silva Menegasso, J.R.A. dos Santos Pinto, K.S. Santos, F.M. Castro, J.E. Kalil, M.S. Palma, Proteomic characterization of the multiple forms of the PLAs from the venom of the social wasp Polybia paulista, Proteomics 11 (2011) 1403-1412, http://dx.doi.org/10.1002/pmic.201000414.

[120] A. Perez-Riverol, A. Musacchio-Lasa, L.G. Romani-Fernandes, J.R.A. Santos-Pinto, G. Oliveira de Azevedo, M.R. Bazon, M.L. Palma, M.S. Zollner, R.L. Brochetto-Braga, Improved Recombinant Production and Immunological Characterization of Phospholipase A1 From Polybia paulista Venom, 2017 (Manuscript in preparation).

[121] G.M. Gibbs, K. Roelants, M.K. O'Bryan, The CAP superfamily: cysteine-rich secretory proteins, antigen 5 , and pathogenesis-related 1 proteins - roles in reproduction, cancer, and immune defense, Endocr. Rev. 29 (2008) 865-897, http://dx.doi.org/ 10.1210/er.2008-0032.

[122] D.R. Hoffman, Hymenoptera venom allergens, Clin. Rev. Allergy Immunol. 30 (2006) 109-128, http://dx.doi.org/10.1385/CRIAI:30:2:109.

[123] T.P. King, L. Kochoumian, T. Lam, Immunochemical observations of antigen 5, a major venom allergen of hornets, yellow jackets and wasps, Mol. Immunol. 24 (1987) 857-864, http://dx.doi.org/10.1016/0161-5890(87)90188-X.

[124] A. Henriksen, T.P. King, O. Mirza, R.I. Monsalve, K. Meno, H. Ipsen, J.N. Larsen, M Gajhede, M.D. Spangfort, Major venom allergen of yellow jackets, Ves v 5: structural characterization of a pathogenesis-related protein superfamily, Proteins Struct Funct. Genet. 45 (2001) 438-448, http://dx.doi.org/10.1002/prot.XXXX. 
[125] R. Suck, B. Weber, H. Kahlert, S. Hagen, O. Cromwell, H. Fiebig, Purification and immunobiochemical characterization of folding variants of the recombinant major wasp allergen Ves v 5 (antigen 5), Int. Arch. Allergy Immunol. 121 (2000) 284-291 (doi:24341).

[126] S. Kischnick, B. Weber, P. Verdino, W. Keller, E.A. Sanders, F.B. Anspach, H. Fiebig, O. Cromwell, R. Suck, Bacterial fermentation of recombinant major wasp allergen Antigen 5 using oxygen limiting growth conditions improves yield and quality of inclusion bodies, Protein Expr. Purif. 47 (2006) 621-628, http://dx.doi.org/10.1016/j. pep.2006.01.009.

[127] S. Blank, H. Seismann, B. Bockisch, I. Braren, L. Cifuentes, M. McIntyre, D. Rühl, J. Ring, R. Bredehorst, M.W. Ollert, T. Grunwald, E. Spillner, Identification, recombinant expression, and characterization of the $100 \mathrm{kDa}$ high molecular weight Hymenoptera venom allergens Api m 5 and Ves v 3, J. Immunol. 184 (2010) 5403-5413, http://dx.doi.org/10.4049/jimmunol.0803709.

[128] J. Köhler, S. Blank, S. Müller, F. Bantleon, M. Frick, J. Huss-Marp, J. Lidholm, E. Spillner, T. Jakob, Component resolution reveals additional major allergens in patients with honeybee venom allergy, J. Allergy Clin. Immunol. 133 (2014)http:// dx.doi.org/10.1016/j.jaci.2013.10.060.

[129] C. Incorvaia, M. Montagni, E. Ridolo, The efficiency of peptide immunotherapy for respiratory allergy, Expert. Rev. Clin. Pharmacol. 9 (2016) 831-837.

[130] S. Blank, H. Seismann, Y. Michel, M. McIntyre, L. Cifuentes, I. Braren, T. Grunwald, U. Darsow, J. Ring, R. Bredehorst, M. Ollert, E. Spillner, Api m 10, a genuine A. mellifera venom allergen, is clinically relevant but underrepresented in therapeutic extracts, Allergy Eur. J. Allergy Clin. Immunol. 66 (2011) 1322-1329, http://dx.doi.org/10. 1111/j.1398-9995.2011.02667.x.

[131] P. Korošec, R. Valenta, I. Mittermann, N. Čelesnik, R. Eržen, M. Zidarn, M. Košnik, Low sensitivity of commercially available rApi $\mathrm{m} 1$ for diagnosis of honeybee venom allergy, J. Allergy Clin. Immunol. 128 (2011) 671-673, http://dx.doi.org/ 10.1016/j.jaci.2011.03.012.

[132] WHO, Antimicrobial resistance, Bull. World Health Organ. 61 (2014) 383-394 http://dx.doi.org/10.1007/s13312-014-0374-3.

133] Y.S. Chan, R.C.F. Cheung, L. Xia, J.H. Wong, T.B. Ng, W.Y. Chan, Snake venom toxins: toxicity and medicinal applications, Appl. Microbiol. Biotechnol. 100 (2016) 6165-6181, http://dx.doi.org/10.1007/s00253-016-7610-9.

[134] L. Xia, Y. Wu, S. Kang, J. Ma, J. Yang, F. Zhang, CecropinXJ, a silkworm antimicrobial peptide, induces cytoskeleton disruption in esophageal carcinoma cells, Acta Biochim. Biophys. Sin. Shanghai 46 (2014) 867-876, http://dx.doi.org/10.1093/ abbs/gmu070.

[135] E. Jamasbi, A. Mularski, F. Separovic, Model membrane and cell studies of antimicrobial activity of melittin analogues, Curr. Top. Med. Chem. 16 (2016) 40-45.

[136] N.G. De Oliveira Junior, M.H.E. Silva Cardoso, O.L. Franco, Snake venoms: attractive antimicrobial proteinaceous compounds for therapeutic purposes, Cell. Mol. Life Sci. 70 (2013) 4645-4658, http://dx.doi.org/10.1007/s00018-013-1345-X.

[137] S.J. Lam, N.M. O'Brien-Simpson, N. Pantarat, A. Sulistio, E.H.H. Wong, Y.-Y. Chen, J.C Lenzo, J.A. Holden, A. Blencowe, E.C. Reynolds, G.G. Qiao, Combating multidrug-resistant Gram-negative bacteria with structurally nanoengineered antimicrobial peptide polymers, Nat. Microbiol. 1 (2016) 16162, http://dx.doi.org/10.1038/ nmicrobiol.2016.162.

[138] K. Wang, J. Yan, B. Zhang, J. Song, P. Jia, R. Wang, Novel mode of action of polybiaMPI, a novel antimicrobial peptide, in multi-drug resistant leukemic cells, Cancer Lett. 278 (2009) 65-72, http://dx.doi.org/10.1016/j.canlet.2008.12.027.

[139] W. Aoki, M. Ueda, Characterization of antimicrobial peptides toward the development of novel antibiotics, Pharmaceuticals. 6 (2013) 1055-1081, http://dx.doi.org/ 10.3390/ph6081055.

[140] F. Fratini, G. Cilia, B. Turchi, A. Felicioli, Insects, arachnids and centipedes venom: a powerful weapon against bacteria. A literature review, Toxicon (2017) 25, http:// dx.doi.org/10.1016/j.toxicon.2017.02.020.

[141] M. Tonk, A. Vilcinskas, M. Rahnamaeian, Insect antimicrobial peptides: potential tools for the prevention of skin cancer, Appl. Microbiol. Biotechnol. 100 (2016) 7397-7405, http://dx.doi.org/10.1007/s00253-016-7718-y.

[142] M.P. Dos Santos Cabrera, S.T.B. Costa, B.M. De Souza, M.S. Palma, J.R. Ruggiero, J. Ruggiero Neto, Selectivity in the mechanism of action of antimicrobial mastoparan peptide Polybia-MP1, Eur. Biophys. J. 37 (2008) 879-891, http://dx.doi.org/10. 1007/s00249-008-0299-7.

[143] M.-T. Lee, W.-C. Hung, F.-Y. Chen, H.W. Huang, Many-body effect of antimicrobial peptides: on the correlation between lipid's spontaneous curvature and pore formation, Biophys. J. 89 (2005) 4006-4016, http://dx.doi.org/10.1529/biophysj.105. 068080 .

[144] K. Wang, J. Yan, R. Chen, W. Dang, B. Zhang, W. Zhang, J. Song, R. Wang, Membrane-active action mode of polybia-CP, a novel antimicrobial peptide isolated from the venom of Polybia paulista, Antimicrob. Agents Chemother. 56 (2012) 3318-3323, http://dx.doi.org/10.1128/AAC.05995-11.

[145] K. Wang, J. Yan, W. Dang, J. Xie, B. Yan, W. Yan, M. Sun, B. Zhang, M. Ma, Y. Zhao, F. Jia, R. Zhu, W. Chen, R. Wang, Dual antifungal properties of cationic antimicrobial peptides polybia-MPI: membrane integrity disruption and inhibition of biofilm formation, Peptides 56 (2014) 22-29, http://dx.doi.org/10.1016/j.peptides.2014.03. 005.

[146] K. Wang, F. Jia, W. Dang, Y. Zhao, R. Zhu, M. Sun, S. Qiu, X. An, Z. Ma, Y. Zhu, J. Yan, Z. Kong, W. Yan, R. Wang, Antifungal effect and action mechanism of antimicrobial peptide polybia-CP, J. Pept. Sci. 22 (2016) 28-35, http://dx.doi.org/10.1002/psc. 2835.

[147] R. Siegel, K. Miller, A. Jemal, Cancer statistics, 2015, CA Cancer J. Clin. 65 (2015) 29, http://dx.doi.org/10.3322/caac.21254.

[148] Q. Zhang, Y. Feng, D. Kennedy, Multidrug-resistant cancer cells and cancer stem cells hijack cellular systems to circumvent systemic therapies, can natural products reverse this? Cell. Mol. Life Sci. (2016) 1-25, http://dx.doi.org/10.1007/s00018016-2362-3.

[149] W. Zhang, J. Li, L.W. Liu, K.R. Wang, J.J. Song, J.X. Yan, Z.Y. Li, B.Z. Zhang, R. Wang, A novel analog of antimicrobial peptide polybia-MPI, with thioamide bond substitution, exhibits increased therapeutic efficacy against cancer and diminished toxicity in mice, Peptides 31 (2010) 1832-1838, http://dx.doi.org/10.1016/j.peptides.2010. 06.019. 